Note

\title{
When Fathers' Rights Are Mothers' Duties: The Failure of Equal Protection in Miller v. Albright
}

\author{
Kristin Collins
}

Lorelyn Penero Miller was born in the Philippines on June 20, 1970. Like approximately 30,000 to 50,000 other children born in the Philippines during the twentieth century,' Lorelyn is the nonmarital child of an American serviceman father and a Filipina mother, Charlie Miller and Luz Penero. ${ }^{2}$ In 1992 Charlie Miller recognized Lorelyn as his child and signed a Voluntary Paternity Decree in Texas state court "legitim[ating]" Lorelyn at birth under Texas state law. ${ }^{3}$ With the paternity decree in hand, Lorelyn applied to the State Department for registration as a United States citizen and was promptly rejected. The State Department claimed that Lorelyn was not a citizen, because Charlie Miller had not legitimated her prior to her twenty-first birthday, as required by 8 U.S.C. $\$ 1409 .{ }^{\star}$ In 1993 Charlie and Lorelyn sued in federal court claiming that Charlie was the victim of unconstitutional sex discrimination. Their argument was straightforward: Federal law regulates American men's ability to transmit citizenship to foreign-born nonmarital children more rigorously than women's, violating Charlie's equal protection rights. ${ }^{5}$ Although $\S 1409$ clearly employs sex-

1. See Elizabeth Kolby, Comment, Moral Responsibility to Filipino Amerasians: Potential Immigration and Child Support Alternatives, 2 ASLAN L.J. 61, 61 (1995).

2. See Miller v. Albright, 523 U.S. 420, 423 (1998) (Stevens, J., plurality opinion).

3. Id at 426.

4. 8 U.S.C. \$ 1409(a)(4) \& note (1994). Section 1409(a)(4) requires that, in order to transmit citizenship, fathers must recognize nonmarital children prior to age 18 . Because Lorelyn was born prior to 1986, her case was decided under the older, more liberal version of the statute, requiring paternal recognition by age 21. See Miller, 523 U.S. at 426 n.3 (Stcvens, J., plurality opinion).

5. See Miller, 523 U.S. at 426. Although not at issue in the Millers'adjudication. $\$ 1409$ (a) provides several other criteria that citizen fathers must meet:

(1) a blood relationship between the person and the father is established by clear and convincing evidence,

(2) the father had the nationality of the United States at the time of the person's birth. 
based classifications-generally a red flag for unconstitutional sex discrimination ${ }^{6}$-in a fractured decision in Miller v. Albright, a majority of the Supreme Court refused to hold that $\S 1409$ is unconstitutional.?

(3) the father (unless deceased) has agreed in writing to provide financial support for the person until the person reaches the age of 18 years, and

(4) while the person is under the age of 18 years-

(A) the person is legitimated under the law of the person's residence or domicile,

(B) the father acknowledges paternity of the person in writing under oath, or

(C) the paternity of the person is established by adjudication of a competent court.

8 U.S.C. $\$ 1409$ (a). Unlike mothers of foreign-born nonmarital children, Charlie Miller also had to meet a five-year U.S. residency requirement. See id. § $1401(\mathrm{~g})$.

6. See Personnel Adm'r v. Feeney, 442 U.S. 256, 272 (1979) (holding that, in order to bring an equal protection challenge, the plaintiff must make a prima facie showing that the challenged law employs sex-based classifications and does not simply disparately impact women). Under current equal protection doctrine, varying degrees of "scrutiny" are triggered by "suspect classifications," such as race or sex. While race-based classifications are presumptively invalid and therefore trigger "strict scrutiny," see Adarand Constructors v. Peña, 515 U.S. 200, 227 (1995) (plurality opinion), sex-based classifications are subject to a slightly lesser level of judicial inquiry, "intermediate" scrutiny, see United States v. Virginia, 518 U.S. 515,533 (1996).

7. The opinions in Miller are somewhat confounding because the case involved a statute that regulates parent-child relationships (an area in which equal protection doctrine is hardly crystalline) and citizenship law (an area of law where courts traditionally defer to Congress). Thus, Justice Stevens's explanation for reviewing $\S 1409$ under a deferential standard of scrutiny is not entirely clear. In one footnote he explained that decisions of Congress in matters concerning immigration and naturalization receive special deference, see Miller, 523 U.S. at 434 n.11, but elsewhere in the text of his opinion he explained that $\$ 1409$ does not implicate sex-equality jurisprudence because under the statute factors other than the sex of the parents determine citizenship (for example, marital status and post-birth conduct), see id. at 443. Chief Justice Rehnquist joined Justice Stevens in affirming the judgment of the court of appeals, maintaining that $\S 1409$ 's use of sex-based classifications merited deference. See id. at 423-44. Justice O'Connor, joined by Justice Kennedy, held that Lorelyn Miller lacked standing to raise her father's equal protection claim but that absent the standing barrier, §1409 would garner intermediate scrutiny and under that standard would be unconstitutional. See id. at 444-52. Justice Scalia, with Justice Thomas, argued that Congress has plenary power in the area of citizenship law, and that therefore courts lack the power to remedy the deprivation of citizenship. See id. at 452-59. Justices Ginsburg, Breyer, and Souter signed on to two dissenting opinions maintaining that $\$ 1409$ should be analyzed using the heightened scrutiny afforded other sex-based classifications, and under that standard $\$ 1409$ is unconstitutional. See id. at 459, 471. Thus, despite the outcome in Miller, five Justices agreed that intermediate scrutiny applies to parentingrelated laws even in the area of citizenship (Justices Breyer, Ginsburg, Souter, O'Connor, and Kennedy) while only two Justices concluded that rational review should be used (Justice Stevens and Chief Justice Rehnquist). Justices Scalia and Thomas did not address this issue in Miller.

Given the fractured nature of the Miller plurality, it is not surprising that lower courts have divided over whether Miller requires them to employ the intermediate scrutiny test announced in Virginia when assessing parenting-related laws. Compare United States v. Ahumada-Aguilar, 189 F.3d 1121 (9th Cir. 1999) (citing the five-Justice agreement in Miller regarding the level of scrutiny to be applied to parenting-related laws), and Rainey v. Cheever, 510 S.E.2d 823 (Ga.) (holding that a state statute denying the father of a nonmarital child the right to inherit through the child is subject to intermediate scrutiny pursuant to Miller), cert. denied, $119 \mathrm{~S}$. Ct. 2411 (1999), with Hendrix v. Secretary of Health \& Human Servs., No. 97-5667, 1998 WL 432484, at *4 (6th Cir. July 16, 1997) (citing the plurality opinion in Miller to support the claim that sex-based intestacy laws as applied to nonmarital children are "simply a practical consideration" and do not implicate equal protection). The confusion has caused consternation among some members of the Court, as expressed by Justice Thomas in a dissent from the denial of certiorari in Rainey: "[W]hile the fractured decision in Miller may demonstrate the need for additional guidance as to the constitutionality of laws differentiating between fathers and mothers of out-of-wedlock 
The lead plurality and dissenting opinions in Miller divided along a longstanding fissure in gender equal protection jurisprudence and feminist legal theory: the extent to which men's and women's physiologically distinct roles in reproduction justify sex-differentiated treatment of parents. ${ }^{8}$ In the lead plurality opinion in Miller, Justice Stevens argued that $\$ 1409$ does not trigger the Court's gender-equality jurisprudence, because with regard to nonmarital children, men and women are simply not similarly situated. ${ }^{9}$ Disparate allocation of parental rights in such circumstances, Justice Stevens maintained in Miller, is not based on "stereotypes" and does not implicate the "gender equality principle" of the Court's sexequality cases. ${ }^{10}$ In the two dissenting opinions in Miller, Justices Ginsburg and Breyer articulated a very different understanding of equal protection as it applies in the context of reproduction and parenting. Emphasizing that the Court's 1996 decision in United States v. Virginia ${ }^{11}$ had strengthened the rigor with which courts examine sex-based classifications, both dissenting opinions contended that the sex-differentiation of parents in $\S 1409$ fuels, and is fueled by, an unconstitutional gender-based "stereotype":.12 "[a] close connection of mother to child, in contrast to [a] distant or fleeting father-child link." ${ }^{13}$ Employing doctrinal and historical analyses, Justices Breyer and Ginsburg concluded that the injury caused by $\S 1409$ is one of mistake: It wrongly assumes that women's physiological role in procreation ineluctably results in increased maternal rights, and that men's

children, it does not stand for the proposition that all generalizations based on gender are constitutionally infirm." Rainey, 119 S. C. at 2413.

8. For discussions of the role of biological difference in legal and social forms of equality, see, for example, DEBORAH RHODE, JUSTICE AND GENDER: SEX DISCRMINATION AND THE LAW 82 (1989); Judith Olans Brown et al., The Failure of Gender Equaliny: An Essay in Constirutional Dissonance, 36 BUFF. L. REV. 573, 581 (1987) ("The central lesson of the biological differences approach is that formal equality cannot assure true equality when individuals are not, in fact. similarly situated."); Janet L. Dolgin, Status and Contract in Feminist Legal Theory of the Family: A Reply to Bartlett, 12 WOMEN's RTS. L. REP. 103, 103-04 (1990) (critiquing traditional family law as inculcating an essentialized understanding of women as "natural" nurturers and parents): Dorothy E. Roberts, The Genetic Tie, 62 U. CHI. L. REv. 209 (1995) (providing a poststructuralist comparison of the meaning of biological parenting in African-American and whiteAmerican cultures); Wendy W. Williams, The Equality Crisis: Some Reflections on Culture, Courts and Feminism, 14 WOMEN'S RTS. L. REP. 151, 161 (1992) (discussing the Supreme Court's analysis of biological sex differences in Michael M. v. Superior Courn, 450 U.S. 464 (1981)).

9. See Miller, 523 U.S. at 445 (Stevens, J., pluality opinion).

10. Id. at $442-43$ (citing Mississippi Univ. for Women v. Hogan. 458 U.S. 711 (1982); Reed v. Reed, 404 U.S. 71 (1971)).

11. 518 U.S. 515 (invalidating the male-only admission policy of Virginia Military Institute on equal protection grounds).

12. See Miller, 523 U.S. at $469-70$ (Ginsburg, J., dissenting); id. at $482-83$ (Breyer, J., dissenting).

13. Id. at 468 (Ginsburg, J., dissenting). For a discussion of how Miller has weakened the prohibition of gender-based stereotypes, see Roger Craig Green. Case Note, Equal Protection and the Status of Stereotypes, 108 YALE L.J. 1885 (1999). 
noninvolvement in gestation and childbirth necessarily translates to diminished paternal rights.

In Miller, the legal significance of sex-based differences in procreation becomes the touchstone of the debate between the plurality and the dissenters concerning the appropriateness of sex-based allocations of parental rights. In this respect, the case is unexceptional: Biological difference has been the focus of disagreement in the Court's attempt to define the limits of equal protection jurisprudence as applied in the contexts of parenting and reproduction. Likewise, although sex-based rights and duties are at issue in virtually every case involving sex-based regulation of parenting, the Court conducts only the most cursory analysis of the allocation of parental responsibilities. This Note argues that the focus of current equal protection analysis on the nexus of biological sex differences and parental rights is both misled and misleading when used to examine regulatory regimes that bear on parenting and reproduction, such as $\S 1409$. It is misled because it fails to account for the numerous gender-inflected factors-other than "real" biological difference-that underlie the allocation of parental rights, such as marital status and sex-based distribution of parental responsibility; it is misleading because it obfuscates the principal harms caused by the sex-based allocation of parental rights.

An examination of the history of citizenship transmission with special sensitivity to official practices not reflected in the statutory history provided by Justice Ginsburg in Miller reveals that biological difference has not been the sole, or even primary, determinant of parental citizenship transmission in America. During the nineteenth and early twentieth centuries, the transmission of citizenship from parents to children was regulated by the principles of coverture-the common-law regime that determined the rights and responsibilities of parents to children according to marital status and parental sex. Under coverture, men had full legal rights and responsibilities regarding children born in marriage, while women had full legal rights and responsibilities regarding children born out of marriage. ${ }^{14}$ In order to protect men from claims on property and status by illegitimate children, the law imposed no obligation to support or care for their nonmarital children.". Recognizing this legal arrangement, legislators, judges, and administrators limited citizenship transmission from citizen fathers to foreign-born nonmarital children.

The history of coverture and the transmission of American citizenship brings an elementary point into focus: The allocation of parental rights is always correlated with the allocation of parental responsibility. This basic

14. Of course, married women had a duty to care for the children they bore, but the children were the legal responsibility of the husband, not the wife.

15. See infra text accompanying note 68 . 
legal truism, and its numerous implications for citizenship law, suggests that the principal gender injustice caused by $\S 1409$ is not its truncation of fathers' rights, but its creation and perpetuation of a legal regime in which mothers assume full responsibility for foreign-born nonmarital children. Once we recognize this gendered operation of $\S 1409$, broader failures of equal protection analysis come into relief. First, while the jurisprudential understanding has been that legislatures may use sex-based classifications where the law responds to "real" or "inherent" differences between the sexes, ${ }^{16}$ a fuller understanding of coverture demonstrates that such classifications may cause injury even where "real" sex differences abound. Thus, contrary to the opinions of some Justices and lower-court judges, ${ }^{17}$ such laws deserve the utmost skepticism even where the government claims that these laws respond to biological differences between men and women. Indeed, it may be that heightened scrutiny is especially warranted in such circumstances.

Second, and even more broadly, the focus on legal parental responsibility that the history of citizenship transmission invites helps answer a more profound jurisprudential question: Can the Court's current equal protection analysis at any level of scrutiny-rational review or heightened scrutiny -adequately identify how sex-based classifications in parenting-related laws produce and perpetuate gender inequality? As demonstrated in both the lead plurality and dissenting opinions in Miller, both weak and strong applications of the equal protection test fail to reveal the coercive nature of the legal regime underlying $\S 1409 .{ }^{18}$ The commonlaw default rules that undergird $\S 1409$ allocate full legal responsibility for nonmarital children to mothers, while fathers' prerogatives and autonomy are given great deference. ${ }^{19}$ When presented with an equal protection challenge to a parenting-related law, judges assume that unwed mothers have full legal responsibility for children. ${ }^{20}$ Regardless of the level of

16. See, e.g., United States v. Virginia, 518 U.S. 515, 533 (1996) (" 'Inherent differences" between men and women, we have come to appreciate, remain cause for celebration, but not for denigration of the members of either sex or for artificial constraints on an individual's opportunity.").

17. See supra note 7 for a discussion of the divisions on the Court and among the lower courts concerning the level of scrutiny should be applied in equal protection challenges to parenting-related laws.

18. Although the Justices in Miller disagreed concerning the standard of equal protection scrutiny that applied to $\S 1409$, usually the govemment must justify its use of sex-based classifications by demonstrating that the classification is " substantially related" to the furtherance of an "important" government objective. See Virginia, 518 U.S. at 533.

19. By arguing that the common-law regime holds mothers but not fathers legally responsible for the support of nonmarital children. I do not mean to suggest that, absent such legal default rules, social and cultural pressures would not shape parent-child relationships in similar directions.

20. See, e.g., Lehr v. Robertson, 463 U.S. 248 (1983) (upholding a New York statute giving mothers unilateral authority over the adoption of a nonmarital child if the father had not registered with a state registry); Parham v. Hughes, 441 U.S. 347 (1979) (upholding a stalute precluding the 
scrutiny that $\S 1409$ receives, under the Court's current equal protection doctrine, the a priori assignment of legal maternal responsibility functions as a justification for the sex-based determination of parental rights. The current analysis lends itself to a kind of circularity: Because an unwed mother has superior legal responsibilities, she automatically receives superior parental rights. The default allocation of parental responsibility to unwed mothers, common to so many statutes, ${ }^{21}$ escapes equal protection scrutiny. By failing to provide for a rigorous examination of the distribution of parental responsibility that undergirds § 1409's allocation of parental rights, modern equal protection analysis obfuscates and even reinforces an inequitable allocation of parental responsibility. If equal protection doctrine is to move beyond its current stasis in the context of parenting and reproduction, it must facilitate critical examination of the sex-based regulation of parenting-even where "real" or "inherent" differences are evident. Moreover, it must treat the sex-based allocation of legal parental responsibilities that underlie the determination of parental rights with similar skepticism. Only then might it render an honest appraisal of the function of parental sex in the regulation of reproduction and parenting. ${ }^{22}$

In Part I, I briefly summarize the three opinions in Miller that directly address Lorelyn Miller's equal protection claim and situate them within the larger context of the Court's jurisprudence regarding parenting and reproduction. I pay special attention to Justice Stevens's defense of the default rule of legal maternal responsibility for nonmarital children, and to Justice Ginsburg's historical account of American citizenship law. In Part II, I revisit the history of $\S 1409$ that Justice Ginsburg provided in her Miller dissent, expanding on her historical analysis to account for the

father of a nonmarital child from suing for the wrongful death of the child). Only once has the Court departed from this reasoning when considering an equal protection challenge. In Caban $v$. Mohammed, 441 U.S. 380 (1979), the Court held that a father who had lived with his nonmarital children as part of a family unit could contest an adoption proceeding initiated by the mother and her new husband.

21. In addition to citizenship law, other types of statutes that often distinguish between men and women as parents include immigration, wrongful death, intestacy, adoption, and custody.

22. While only implicitly discussed in the equal protection case law, the relationship among parental rights, responsibility, parental sex, and marriage has been examined by feminist legal theorists. See, e.g., Katharine T. Bartlett, Re-Expressing Parenthood, 98 YaLE L.J. 293 (1988) (arguing that the current focus on parental rights is misled and that the law should be more concerned with monitoring and rewarding parental responsibility); Karen Czapanskiy, Volunteers and Draftees: The Struggle for Parental Equality, 38 UCLA L. REV. 1415, 1458 (1991) (arguing that family law recognizes "mothers as draftees who are expected to do all the necessary parenting and fathers as volunteers who may contribute something to their child if they so desire"); Dolgin, supra note 8; Nancy E. Dowd, Rethinking Fatherhood, 48 FLA. L. REV. 523 (1996) (arguing for a gender-neutral approach to parenting in which men assume the role of coequal nurturers); Mary $\mathrm{L}$. Shanley, Unwed Fathers' Rights, Adoption, and Sex Equality: Gender-Neutrality and the Perpetuation of Patriarchy, 95 COLUM. L. REV. 60 (1995) (arguing that giving unwed fathers equal standing to contest adoption proceedings is a perpetuation of patriarchy's investment in paternal rights). 
practices of the various government institutions involved in citizenship transmission. I detail the system of coverture that undergirded the statutes and practices of citizenship transmission throughout the nineteenth and early twentieth centuries. In Part III, I explore the implications of this history - and the sex-based allocation of legal parental responsibility that it reveals-both for $\S 1409$ and for the application of equal protection analysis to the legal regulation of parenting and reproduction. I conclude in Part IV with a modest proposal for how courts could expand their analyses of parenting-related laws to provide fuller accounts of the inequity of the current default allocation of parental responsibility out of wedlock.

\section{MILLER AND THE FAILURE OF THE "EQUALITY PRINCIPLE"}

While litigating Miller, the government argued that $\S 1409$ 's rigorous criteria for father-child citizenship transmission help achieve two objectives: minimizing fraudulent citizenship claims and ensuring a bona fide relationship between the citizen father and the foreign-born child. ${ }^{23}$ Concurring with the government's basic argument, Justice Stevens made a fairly bold assertion: "The gender equality principle that was implicated in [the Court's previous sex-discrimination cases] is only indirectly involved in this case ...." ${ }^{24}$ In other words-and contrary to the dissenters--Justice Stevens argued that $\S 1409$ does not rely on sex stereotypes or even sexbased classifications of the sort recognized (and repudiated) by the Court's equal protection doctrine. In this Part, I examine the lead plurality and the dissenting opinions in Miller, and situate them within a larger tradition of equal protection case law involving parenting and reproduction.

\section{A. Justice Stevens on Motherhood: Voluntary Conduct or Sex-Based Classification?}

In Miller, Justice Stevens argued that because an unwed mother chooses to carry a child to term and then assumes legal responsibility for the child, Congress is justified in "rewarding" mothers with the virtually

23. See Brief for the Respondent at 14, 28, Miller v. Albright, 523 U.S. 420 (1998) (No. 96 $1060)$.

24. Miller, 523 U.S. at 442 (Stevens, J., plurality opinion). 
unfettered right $t^{25}$ to transmit citizenship to foreign-born nonmarital children while denying the same to unwed fathers: ${ }^{26}$

[The mother] must first choose to carry the pregnancy to term and reject the alternative of abortion--an alternative that is available by law to many, and in reality to most, women around the world. She must then actually give birth to the child. Section 1409(c) rewards that choice and that labor by conferring citizenship on her child. ${ }^{27}$

In contrast to the mother's purportedly active role, Justice Stevens described the supposedly passive role of the unmarried father. Under $\S 1409$, the father "need not participate in the decision to give birth rather than to choose an abortion... [or even] be present at the birth." ${ }^{28}$ Indeed, "for at least 17 years thereafter he need not provide any parental support, either moral or financial, to either the mother or the child" and can still transmit his citizenship by meeting the listed criteria. ${ }^{29}$ Because of the "vast

25. The only requirement that $\S 1409$ imposes on the citizen mother of a foreign-born nonmarital child is one year of continuous residence in the United States at some time during her life. See 8 U.S.C. $\$ 1409$ (c) (1994). In addition to the requirements set out in § 1409(a), see supra note 5 , the father of a foreign-born nonmarital child must also fulfill a five-year residency requirement, see 8 U.S.C. \& 1401 (g).

26. The term "unwed fathers" is slightly underinclusive of the class of fathers affecled by $\S 1409$, since a man may be married and also the father of a child born to a woman not his wife. For the purposes of this Note, however, I use "unwed father" to indicate the father of a child born to a woman not his wife.

27. Miller, 523 U.S. at 433-34 (Stevens, J., plurality opinion). Justice Stevens provided no support for his claim that abortion is an "alternative that is available by law to many, and in reality to most, women around the world." Id. at 433. Justice Stevens's suggestion that women's reproductive choice is dispositive of the father-child relationship is conceptually flawed: Were that the case, the choice not to abort could be used to argue that unwed fathers should not have any parental rights or responsibilities, a position that runs counter to the Cour's due process case law. See, e.g., Stanley v. Illinois, 405 U.S. 645 (1972) (holding that a state's presumption of an unwed father's "unfitness" as a parent violates due process). Such an argument was, in fact, made following the Court's decision in Roe v. Wade, 410 U.S. 113 (1973). See, e.g., George S. Swan, Abortion on Maternal Demand: Paternal Support Liability Implications, 9 VAL. U. L. REv. 243 (1975). From a policy perspective, Justice Stevens's reasoning is simply unwise, insofar as it treats illegal (and hence generally unsafe) abortions as a realistic "choice" for women in countrics where abortion is illegal. As a case in point, 8600 nonmarital children of Filipino mothers and U.S. servicemen fathers brought a class action against the United States in the Court of Claims, see Acebedo v. United States, No. 93-124C (Fed. Cl. Nov. 5, 1993), for breach of implied contract. The named plaintiff was Christopher Acebedo, a child born with serious birth defects due to a botched abortion.

Just as a father's claim to parental rights and responsibilities does not hinge on whether a woman has a legal (or extralegal) right to choose whether to terminate her pregnancy, so an unmarried woman's right to choose is not limited by the father's claim to parental rights. Thus. although fathers have parental rights and responsibilities vis-à-vis their legitimate children, the Supreme Court in Planned Parenthood v. Casey, 505 U.S. 833, 895 (1992), invalidated a law requiring married women to notify their husbands before obtaining an abortion.

28. Miller, 523 U.S. at 434 (Stevens, J., plurality opinion).

29. Id. Justice Stevens refers in this passage to the 1986 version of 8 U.S.C. $\$ 1409$ when he identifies 18 as the cutoff age for citizenship transmission to nonmarital children. Lorelyn was evaluated under the prior version of the statute, see supra note 4 , and thus her cutoff age was 21 . 
difference between the burdens imposed on the respective parents of" foreign-born nonmarital children, ${ }^{30}$ Justice Stevens reasoned that the government is justified in regulating the right to transmit citizenship according to parental sex.

Although Justice Stevens emphasized the importance of the mother's choice in bearing children as a predicate to her superior assumption of parental rights and responsibilities, his description of the difference between mothers and fathers-and the choices they make-portrays such differences and choices as biologically determined. For example, under Justice Stevens's analysis "birth" is "an event creating a legal relationship between [mother] and child," while conception (a physiological event shared by both mother and father) has substantially less legal significance. ${ }^{31}$ Distilled to its basic structure, Justice Stevens's argument takes the following form: Women choose to bear children, a willed physiological event that warrants the default allocation of parental responsibility for nonmarital children to the mother, which in turn justifies allocation of superior maternal rights. In turn, men's "natural" lack of responsibility for nonmarital children justifies limiting unwed fathers' right to transmit citizenship. ${ }^{32}$

This type of reasoning is, in fact, familiar in the Court's equal protection jurisprudence. In a long line of pre-Virginia cases involving fathers' challenges to statutes that privilege the mother-child relationship out of wedlock, the Court has upheld sex-based allocations of parental rights, reasoning that a father's lack of legal responsibility for nonmarital children justifies such discrimination. For example, in Lehr $v$.

30. Miller, 523 U.S. at 434 (Stevens, J., plurality opinion).

31. Id. at 443; see also id at 435 ("The substantive conduct of the unmarried citizen mother that qualifies her child for citizenship is completed at the moment of birth . . ..").

32. Justice Stevens's emphasis on parental choice and conduct is curious, if not paradoxical. given his understanding of mothers' physiological role in childbirth: He contends both that women are the "natural" caretakers of children and that they choose that role. Nevertheless, his portrayal of procreation as voluntary has profound doctrinal implications. In Justice Stevens's understanding of the equal protection doctrine, a statute that responds to individuals' choiceseven where those choices are themselves predetermined by an individual's sex-does not employ sex-based classifications per se. According to this logic, a statute that allocales rights on the basis of parental sex does not involve sex stereotypes, because such statutes acmally distinguish between parents on the basis of conduct (for example, birth, assumption of parental responsibilities). Thus, in Miller, Justice Stevens argued that regardless of the standard of equal protection "scrutiny" used to analyze \$1409-"rational review" or "intermediale scrutiny"-the use of sex-based classifications in parenting-related laws does not run afoul of the Court's gender "equality principle." See id. at 434 n.11. This line of logic comports well with the Court's endorsement of "immutability" as an indicator of a "suspect classification." and its resistance to extending heightened scrutiny to characteristics that the individual can purportedly control. For a recent (and rich) discussion of the "immutable" sex characteristics versus "conduct" debate, see Kenji Yoshino, Assimilationist Bias in Equal Protection: The Visibility Presumption and the Case of "Don't Ask, Don't Tell," 108 YALE L.J. 485. 493-96 (1998). See also Janet E. Halley. Sexual Orientation and the Politics of Biology: A Critique of the Argument from Immutability. 46 STAN. L. REV. 503 (1994). 
Robertson ${ }^{33}$ - the precedent upon which Justice Stevens depended most heavily in Miller $^{34}$ - the Court upheld a New York statute denying an unwed father equal authority to veto an adoption proceeding, on the grounds that he had failed to assume parental responsibility for his child, even though the record revealed that he had made a determined effort to do so. ${ }^{35}$ In numerous other cases, such as Quilloin $v$. Wallcott ${ }^{36}$ and Parham $v$. Hughes, ${ }^{37}$ the Court has used similar reasoning to deny fathers equal parental rights. The tacit assumption in this line of cases is that the mother's physiological role in childbirth justifies both her greater responsibility and her corresponding superior parental rights. ${ }^{38}$

After the Court's strong condemnation of sex-based classifications and stereotypes in Virginia, it was unclear whether the logic of cases such as Lehr would remain viable. ${ }^{39}$ According to Justice Stevens's plurality opinion in Miller, Virginia's prohibition of sex-based classifications is simply inapplicable to $\S 1409$ because such a regulation does not implicate the "gender equality principle" of the Court's equal protection jurisprudence: A distinction drawn on the basis of sex is not cognizable as discrimination when it involves parenting or reproduction. ${ }^{40}$ Moreover, although he maintained that the heightened scrutiny afforded other sexbased classifications did not apply to $\S 1409$, Justice Stevens reasoned that the statute would survive even the rigorous Virginia standard of review because regulation of parental rights on the basis of sex is justified by

33. 463 U.S. 248 (1983).

34. See Miller, 523 U.S. at $437-40$ (Stevens, J., plurality opinion) (citing Lehr, 463 U.S. at 257).

35. See Lehr, 463 U.S. at 269 (White, J., dissenting).

36. 434 U.S. 246 (1978) (upholding a state statute that gave the unwed mother unilateral authority to consent to the adoption of the child).

37. 441 U.S. 347 (1979) (holding that a state may require the father to "legitimate" his nonmarital child before he is accorded legal parental rights).

38. The purported nexus between women's physiological role in childbearing and parental responsibility has been used to justify sex-differentiated regimes outside the immediate context of parental rights. In Michael M. v. Superior Court, 450 U.S. 464 (1981), the Court upheld a statutory rape law that held men over 18 criminally liable for engaging in sexual intercourse with females under 18, but did not punish women over 18 for engaging in sexual intercourse with males under 18. The Court argued that the "physical, emotional, and psychological consequences" of teenage pregnancies lie with women, rather than with men, thus justifying the sex-differentinted statute. Id. at 471.

39. One author suggested that Virginia effectively overruled Geduldig v. Aiello, 417 U.S. 484 (1974), which had held that distinctions based on pregnancy did not constitute gender discrimination. See Candace S. Kovacic-Fleischer, United States v. Virginia's New Gender Equal Protection Analysis with Ramifications for Pregnancy, Parenting, and Title VII, SO VAND. L. REV. 845 (1997). The lead plurality in Miller disagreed.

40. See Miller v. Albright, 523 U.S. 420, 434 n.11 (1998) (Stevens, J., plurality opinion). Sec supra note 7 for a discussion of Justice Stevens's explanations for why $\$ 1409$ should not be subject to rigorous scrutiny. 
biological differences between fathers and mothers, and by women's "choice" to bear children out of wedlock. ${ }^{41}$

\section{B. Justices Ginsburg and Breyer on Maternal Stereotyping}

Justices Ginsburg and Breyer's assessment of how Virginia bears on government regulation of parenting and reproduction differed dramatically from that of Justice Stevens. Writing virtual companion-piece dissents, Justices Breyer and Ginsburg attacked $\S 1409$ using the "undiluted" 42 standard of heightened scrutiny and the prohibition on gender stereotypes announced in Virginia. ${ }^{43}$ Using this test, Justice Breyer argued that "the relationship between the statutory [gender-based] requirements" and the statute's purported objectives "is one of total misfit." + Since there is nothing "inherent" 45 about women's physiological role in reproduction that determines which parent assumes responsibility for, or develops a relationship with, the child, the prohibited "generalization that mothers, not fathers, ... act as caretaker parents" cannot be used to determine the child's citizenship. ${ }^{46}$ In making this argument, Justice Breyer seemed to reject silently the logic of cases such as Lehr that recognized a nexus between childbearing and parental rights and responsibilities. In her dissenting opinion, Justice Ginsburg seconded Justice Breyer's doctrinal analysis and argued that the sex-based classifications at issue in $\S 1409$ are based on impermissible stereotypes ${ }^{47}$ that reinforce sex-based stratification of parental responsibility: " $[\mathrm{M}]$ others, as a rule, are responsible for a child born out of wedlock; fathers unmarried to the child's mother, ordinarily, are not." 48

To demonstrate the origins of the sex-based classifications and stereotypes employed in $\S 1409$, Justice Ginsburg provided a detailed description of how American citizenship law has historically differentiated between mothers' and fathers' ability to transmit citizenship. "The history of the treatment of children born abroad to United States citizen parents," she argued, "counsels skeptical examination of the Government's prime explanation for the gender line drawn by $\S 1409$ - the close connection of mother to child, in contrast to the distant or fleeting father-child link." 49 Justice Ginsburg documented how, for much of American history,

41. Miller, 523 U.S. at 434 n.11, 444-45 (Stevens, J., plurality opinion).

42 Id at 481 (Breyer, J., dissenting).

43. See United States v. Virginia, 518 U.S. 515.530 (1996).

44. Miller, 523 U.S. at 484 (Breyer, J., dissenting).

45. Virginia, 518 U.S. at 533.

46. Miller, 523 U.S. at 484 (Breyer, J., dissenting).

47. See id. at $\mathbf{4 6 0}$ (Ginsburg, J., dissenting).

48. Id.

49. Id. at 468 . 
citizenship statutes limited women's rights by expatriating them upon marriage to non-citizens and by preventing women from transmitting citizenship to their foreign-born children. ${ }^{50}$ Prior to 1934, Justice Ginsburg contended, only fathers could transmit citizenship to nonmarital children. According to her interpretation, Congress partially remedied this inequality in the 1930s and 1940s by passing citizenship statutes that granted mothers (including unwed mothers) the right to transmit citizenship. ${ }^{51}$ At the same time, however, Congress introduced new inequality by severely limiting fathers' rights to transmit citizenship in the nonmarital context. ${ }^{52}$ Given Justice Ginsburg's interpretation of the sources, § 1409-which favors the mother-child relationship-represents a departure from an equally disturbing past in which only fathers were able to transmit citizenship to their children. "During most of our Nation's past," Justice Ginsburg observed, "laws on the transmission of citizenship from parent to child discriminated adversely against citizen mothers,' not against citizen fathers." 53

\section{AN EXPANDED HISTORY OF $§ 1409$}

Justice Ginsburg used the history of American citizenship law as evidence that gender stereotypes have functioned in citizenship transmission since the Founding, and to intimate that $\$ 1409$ is a modern, father-disadvantaging incarnation of ongoing discriminatory practices. While this is certainly the case, and while Justice Ginsburg's account of the statutory regime regulating citizenship transmission is accurate, an expanded history-taking into account practices not reflected in the statutes-reveals a much more nuanced and problematic motherdisadvantaging tradition of citizenship transmission. ${ }^{54}$ Justice Ginsburg correctly observed that the Act of 1934 and the Nationality Act of 1940 were innovations in the sense that they granted married and unmarried women a statutory right to transmit citizenship. However, the impact of

50. See id. at 461-68 (citing Act of Feb. 10, 1855, ch. 70, 10 Stat. 604, 604: Act of Apr. 14. 1802, ch. 28, 2 Stat. 153, 155; Act of Jan. 29, 1795, ch. 20, 1 Stat. 414, 415; Act of Mar. 26. 1790. ch. 3,1 Stat. 103, 104).

51. See id. at 465-67 (citing Nationality Act of 1940, ch. 876, $\$ 201,205,54$ Stat. 1137 , 1138-40; Act of May 24, 1934, ch. 344, 48 Stat. 797, 797).

52. See id. at 467.

53. Id. at 461 .

54. For discussions of the role of coverture in citizenship law, sec CANDICE LewIS BREDBENNER, A NATIONALITY OF HER OWN: WOMEN, MARRIAGE, AND THE LAW OF CITIZENSHIP 84 (1998); LINDA K. KERBER, NO CONSTITUTIONAL RIGHT TO BE LADIES: WOMEN AND THE OBLIGATIONS OF CITIZENSHIP 33-43 (1998); Nancy F. Cott, Marriage and Women's Citizenship in the United States, 1830-1934, 103 AM. HIST. REV. 1440, 1455-58 (1998); and Virginia Sapiro, Women, Citizenship, and Nationality: Immigration and Naturalization Policies in the United States, 13 POL. \& SOC'Y 1, 3-4 (1984). 
these statutes with regard to unwed mothers and their foreign-born children may have been limited. While it is true that prior to the Act of 1934 married women could not transmit citizenship to their foreign-born children, and that unwed mothers lacked a statutory right to do so prior to the Nationality Act of 1940, in practice unwed mothers transmitted citizenship to foreignborn children before they gained a statutory right to do so..$^{\text {ss }}$ At the same time, although pre-1940 statutes gave "fathers" the right to transmit citizenship, case law reveals that this right did not extend to unwed fathers; such fathers could transmit citizenship under very limited circumstances only.$^{56}$ Section 1409 was an innovation in relation to unmarried parents only insofar as it codified the existing practice: From at least the early twentieth century, American women could transmit citizenship to nonmarital children born abroad much more readily than could American men.

Understanding how and why citizenship law historically differentiated between men and women as parents requires an understanding of coverture-the common-law doctrine used to determine the rights and responsibilities of parents and children. From the nineteenth to the early twentieth centuries, the principles of coverture informed legislators' and judges' interpretations of citizenship laws, as well as the practices of immigration officials implementing those laws. Guided by these longstanding principles, citizenship was transmitted from parent to child according to parental sex and marital status. In this Part, I explain how coverture regulated parental rights and responsibilities under the common law. I then demonstrate how judges, legislators, and officials incorporated coverture into American citizenship law throughout the nineteenth and early twentieth centuries. Finally, I review the congressional hearings during which feminist lobbyists mobilized a massive-but incompleteexpurgation of coverture from American citizenship laws in the 1930s.

Careful analysis of coverture's incorporation into citizenship law illuminates the operation of parental sex in American citizenship transmission in two important respects. First, it demonstrates that Congress reasoned about parenting, not from certain stereotypical understandings of biological sex-differentiation, but from specific legal understandings of parental responsibility that corresponded to marital status and sex. Second, an expanded history of American citizenship transmission reveals that the

55. Justice Ginsburg recognized that unwed mothers sometimes transmitted citizenship in the pre-1940 era, see Miller, 523 U.S. at 463 (Ginsburg. J., dissenting), but de-emphasized the significance of that deparure from statute. Although it is unclear why Justice Ginsburg characterized unwed mothers' ability to transmit citizenship in this manner, it may be that her interpretation was shaped by a need to characterize the discrimination in $\$ 1409$ as discrimination on the basis of sex alone, so as not to complicate the historical narrative with recognition that the statutes also distinguished between married and unmarried persons of the same sex.

56. See infra text accompanying note 103; Section Il.C. 
problem with $\S 1409$ is not simply that it rests on stereotypes of caretaker mothers and uninterested ("fleeting") fathers. Rather, there is a more coercive aspect to the law: It assumes and perpetuates a legal rule that assigns full responsibility for nonmarital children to mothers, leaving similarly situated men free from the burdens of parenthood.

\section{A. Coverture and Parental Responsibility in American History}

Historians have long criticized the doctrine of coverture for denying married women basic political, civil, and legal rights. ${ }^{57}$ Once married, the feme covert's legal identity was "merged" with that of her husband under the legal fiction of "marital unity." 58 Under this doctrine the wife lost the legal rights she had as a feme sole, such as rights to her property and her labor, access to courts, and the right to contract independently of her husband..$^{59}$ In return she gained the protection, or "cover," of her husband, which included a right to basic support. ${ }^{60}$ Although less frequently noted, coverture also determined the legal rights and responsibilities of each parent to his or her children. In marriage, the father had custodial rights over all children, as well as rights to the children's labor. ${ }^{61}$ In return, so to speak, the father was required to support his children, ${ }^{62}$ and they inherited his name, status, property, and domicile. ${ }^{63}$

If only by default, coverture also established the rights and duties of parents outside marriage. Under the strict common law, a nonmarital child

57. See, e.g., NORMA BASCh, IN THE EYES OF THE LAW: WOMEN, MARRIAGE, AND PROPERTY IN NINETEENTH-CENTURY NEW YORK 47-55 (1982); JOAN HOFF, LAW, GENDER, AND INJUSTTCE: A LEGAL HISTORY OF U.S. WOMEN 87-90 (1991).

58. The classic, and often-quoted, articulation of the doctrine of "marital unity" comes from Blackstone's Commentaries:

By marriage, the husband and wife are one person in law: that is, the very being, or legal existence of the woman is suspended during marriage, or at least is incorporated and consolidated into that of the husband: under whose wing. protection, and cover, she performs everything; and is therefore called ... a femecovert... her husband, [is called] her baron, or lord; and her condition during marriage is called her coverture.

1 WILLIAM BLACKSTONE, COMMENTARIES *430.

59. See HOFF, supra note 57 , at 87-88.

60. See BASCH, supra note 57 , at 52 ("Thus the husband ... is responsible for his wife's debts before marriage and for her maintenance during marriage ...."); 1 BLACKSTONE, supra note 58 , at $* 430-31$.

61. See I BLACKSTONE, supra note 58, at *441-42.

62. See 2 James Kent, COMMENTARIES ON AMERICAN Law 161 (12th ed. 1986) (1873) ("The father is bound to support his minor children, if he be of ability, even though they have property of their own; but this obligation in such a case does not extend to the mother."). For cases expressing this basic common-law principle, see Denning v. Star Publishing Co., 180 N.E. 685, 687 (Ind. App. 1932) (in banc), and State v. Jones, 160 S.E. 468, 469 (N.C. 1931).

63. See, e.g., 1 BLACKSTONE, supra note 58, at *436-38. The transmission of status from father to child was less meaningful in America than it had been in England, where status transmission included, for example, nobility, peerage, and serfdom. 
was nullius filius ("nobody's child") and could inherit from neither his mother nor his father. ${ }^{64}$ According to the common law, the putative father had no legal duty to support his "natural child" unless he "adopted [legitimated] the child as his own" - a measure that was left to the father's discretion. ${ }^{65}$ The strict common law also originally prevented the nonmarital child from inheriting property or status from or through his mother, ${ }^{66}$ although many states softened this rule by statute. ${ }^{67}$ Under the common-law tradition that developed in America, then, coverture established default rules that enabled patrilineal status transmission in marriage and matrilineal status transmission outside marriage.

TABle 1. Allocation of Parental RightS AND DUTIES BY

PARENTAL SEX AND MARTTAL STATUS UNDER THE COMMON LAW IN NINETEENTH-CENTURY AMERICA

\begin{tabular}{|c|c|c|}
\hline & Men & Women \\
\hline Married & $\begin{array}{l}\text { Duty to support wife and } \\
\text { children. } \\
\text { Right to custody of children. } \\
\text { Transmission of name, } \\
\text { property, status, and } \\
\text { domicile to children. }\end{array}$ & $\begin{array}{l}\text { - } \quad \text { No duty to support children. } \\
\text { - } \quad \text { No right to custody. } \\
\text { - no transmission of status, } \\
\text { name, or domicile. } \\
\text { - Right to support by } \\
\text { husband. }\end{array}$ \\
\hline $\begin{array}{c}\text { Not } \\
\text { Married }\end{array}$ & $\begin{array}{l}\text { No duty to support children. } \\
\text { - No custodial rights. } \\
\text { - } \quad \text { properansmission of name, } \\
\text { Option to legitimate child. }\end{array}$ & $\begin{array}{l}\text { - } \quad \text { Cuty to support children. } \\
\text { - } \quad \text { Transmistodial rights to children. } \\
\text { status, and domicile under } \\
\text { statute. }\end{array}$ \\
\hline
\end{tabular}

An important objective of these common-law rules was to protect men's interests by ensuring that property and status descended through specific ("legitimate") channels of inheritance, and that nonmarital ("illegitimate") children would have no legal claim to family property or status. ${ }^{68}$ A father had no duty to support his nonmarital children absent a

64. See 2 KENT, supra note 63, at 175; see also 1 BLACKSTONE, supra note 58, at *447 ("[T] he rights are very few, being only such as he can acquire; for he can inheril nothing, being looked upon as the son of nobody, and sometimes called filius nullius....").

65. 2 KENT, supra note 63 , at 178.

66. For cases articulating and upholding this basic common-law principle, see, for example, Hogan v. Hogan, 44 S.W. 953, 954 (Ky. 1898); In re Cady's Estate, 12 N.Y.S.2d 750 (App. Div. 1939); and In re Mericlo, 63 How. Pr. 62 (N.Y. Sup. Cl. 1882).

67. See 2 KENT, supra note 63, at 176 ("'[1]n several of these United States, the rigor of the English law has been relaxed, and bastards can inherit to [sic] their mother equally as if they were her lawful children."). For cases discussing statutory departures from the common law, allowing nonmarital children to inherit through the mother, see Sievenson's Heirs v. Sullivant, 18 U.S. (5 Wheat.) 207, 260 (1820); In re Wardwell, 57 Cal. 484, 491 (1881): Wallace v. Rappleye, 103 IIl. 229, 257 (1882); and McGuire v. Brown, 41 Iowa 650, 658 (1875).

68. See 1 BLACKSTONE, supra note 58 , at $* 435$ ("[E]stablishment of marriage in all civilized states is built on this natural obligation of the father to provide for his children; for that ascenains 
statutory departure from the common law. ${ }^{69}$ By contrast, in the words of the chronicler of the American common law James Kent, the mother was "bound to maintain [the child] as its natural guardian." ${ }^{70}$ By setting the default rules concerning status transmission and custodial responsibility as it did, the coverture regime allowed men to remain sexually active outside of marriage and to bear virtually none of the material burdens of children born as a consequence.

Early American municipalities were sensitive to the inequalities of maternal liability for nonmarital children imposed by the common-law rules (or, more accurately, to the costs that towns bore if such children became public charges) and passed laws requiring putative fathers to provide support for nonmarital children. ${ }^{71}$ These were, however, deviations from the common law that did not reach unmarried fathers' property or status; nonmarital children were not heirs and could not inherit directly or collaterally through the father's blood. ${ }^{72}$ Such laws affected neither the structure of status transmission nor the basic rights and duties between parents and nonmarital children: ${ }^{73}$ The mother remained the source of the nonmarital child's domicile, legal status, and primary support. ${ }^{74}$ Indeed, if a nonmarital child became a public charge because the putative father could not be found and the mother lacked sufficient resources, inheritance of the mother's domicile generally determined that the mother's town was

and makes known the person who is bound to fulfill this obligation ... ."); see also BASCH, supra note 57, at 50 ("[T] hose without property, [Blackstone] insists, have to marry also so that their children will not become burdens on society. Because the children of the poor are potential liabilities, the main end of marriage in 'the lower ranks' is to 'ascertain and fix upon some certain person' the care, protection, maintenance, and education of children." (quoting 1 BLACKSTONE: supra note 58 , at *443)).

69. For cases acknowledging that, absent statutory departures from the common law, the father of a child born out of wedlock had no duty to support that child, sec Glidden v. Nelson. 15 Ill. App. 297, 300 (1884); and State v. Tieman, 73 P. 375, 376 (Wash. 1903).

70. $2 \mathrm{KENT}$, supra note 63 , at 178 . For cases articulating the common-law rule that held the unwed mother solely responsible for support of her child, see Beckett v. State ex rel. Rothert, 30 N.E. 536, 537 (Ind. App. 1892); Easley v. Gordon, 51 Mo. App. 637 (1892): Town of Hudson v. Hills, 8 N.H. 417, 418 (1836); Friesner v. Symonds, 20 A. 257. 259 (N.J. Prerog. Ct. 1890); and Bustamento v. Analla, 1 N.M. 255 (1857).

71. See JAMES SChOuler, A TREATISE ON THE LAw Of THE DOMESTIC RELATIONS 385 (Boston, Little, Brown, \& Co. 1870) ("[T]he main element in such legislation [is] public indemnity against the support of such persons."); see also 2 KENT, supra note 63, at 178 ("The reputed father is liabie to arrest and imprisonment, until he gives security to indemnify the town chargeable with the maintenance of the child. These provisions are intended for the public indemnity ... and similar regulations to coerce the putative father to maintain the child, and indemnify the town or parish, have been adopted in the several states.").

72. See WILFRID HOOPER, THE LAW OF ILLEGITIMACY 107 (1911); 2 KENT, supra notc 63. at 179; see also Heath v. White, 5 Conn. 228, 235 (1824) (holding that because the putative father remains uncertain, he can be held liable for support only).

73. See 1 BLACKSTONE, supra note 58 , at *446; 2 KENT, supra note 63 , at $177-78$.

74. See 2 KENT, supra note 63 , at 178 ("She has a right to the custody and control of [the nonmarital child] as against the putative father, and is bound to maintain [the child] as its natural guardian...."). 
required to support the destitute child, thus minimizing conflicts between towns. $^{75}$

Viewed from the parents' perspectives, then, coverture determined the allocation of parental rights and responsibilities according to marital status and sex. It was this system-and the gendered understanding of parental responsibility outside marriage that it inculcated-that was imported into citizenship law in the nineteenth and early twentieth centuries through a confluence of judicial interpretation, statutory enactment, and institutional practices.

\section{B. Citizenship and Coverture: The Origins of $\$ 1409$}

In English law there was scant intersection between coverture and citizenship law. Citizenship was determined by virtue of place of birth (jus soli), rather than by parentage or "blood" (jus sanguinis). ${ }^{76}$ While honoring jus soli as the primary source of citizenship (a principle eventually enshrined in the Fourteenth Amendment's Citizenship Clause), ${ }^{n}$ from the 1790s onward American statutes also provided for jus sanguinis. Because citizenship jus sanguinis involved the transmission of status from parent to child, coverture was automatically implicated. In providing for the statutory departure from jus soli, legislators and courts from the nineteenth to the early twentieth centuries imported the rules of coverture into citizenship law.

\section{Women, Marriage, and Citizenship}

The first American citizenship statute, enacted in 1790, stipulated that for "children of citizens ... born beyond sea, or out of the limits of the United States," the "right of citizenship shall not descend to persons whose fathers have never been resident in the United States." 78 This statute, reiterated with minor alterations in 1795 and $1802,{ }^{79}$ remained the law of

75. See, e.g., Woodstock v. Hooker, 6 Conn. 35, 37 (1825) (holding that illegitimate children take the settlement of their mother); see also Gerald L. Neuman. The Lost Century of American Immigration Law (1776-1875), 93 COLUM. L. REV. 1833, 1846-59 (1993) (discussing the implications of the poor laws for interstate immigration in American history): William P. Quigley. The Quicksands of the Poor Law: Poor Relief Legislation in a Growing Nation, 1790-1820, $18 \mathrm{~N}$. ILL. U. L. REV, 1, 82-83 (1997) (discussing the relevance of the mother's domicile in American poor-relief statutes).

76. See CATHERYN SECKLER-HUdSON, STATELESSNESS 197 (1934); FREDERICK VAN DYNE, CITIZENSHIP OF THE UNITED STATES 32 (1904).

77. U.S. CONST. amend. XIV ("All persons bom or naturalized in the United States ... are citizens of the United States and of the State wherein they reside.").

78. Act of Mar. 26, 1790, ch. 3, 1 Stat. 104, 104 (emphasis added).

79. See Miller v. Albright, 523 U.S. 420, 461 (1998) (Ginsburg, J., dissenting) (citing Act of Apr. 14, 1802, ch. 28, § 4, 2 Stat. 153, 155; Act of Jan. 29, 1795. ch. 20. § 3, 1 Stat. 414, 415). 
the land for sixty-five years. As Justice Ginsburg correctly observed in Miller, the early citizenship statutes were riddled with ambiguities. First, the words "children of citizens" could mean that as long as one or both of the child's parents were citizens, the child born abroad would qualify for citizenship (if the father had resided in the United States). Alternatively, read with the proviso concerning the residence of the father, "children of citizens" might suggest that only the father's citizenship was relevant for purposes of citizenship transmission. ${ }^{80}$ Second, and most significantly for present purposes, these statutes were completely silent concerning the citizenship status of a nonmarital child born abroad to either a citizen father or a citizen mother. ${ }^{81}$

Although the wording of these statutes seems vague to the modern reader, the early citizenship laws regulating jus sanguinis posed few interpretive difficulties during the nineteenth and early twentieth centuries because they were understood by courts and refined by legislatures according to the well-entrenched norms of coverture. Coverture supplied the interpretive template in terms of both how marriage affected the citizenship of the feme covert and how it affected citizenship of children born in and out of marriage. For example, in 1854, Congress remedied any confusion concerning whether "children of citizens" included foreign-born children of a mixed-nationality couple in which only one parent was American. Both of Congress's principal amendments to the citizenship statute further encoded the principles of coverture. First, Congress clarified that only children whose "fathers were or shall be at the time of their birth citizens of the United States, shall be deemed... citizens of the United States," ${ }^{82}$ thereby codifying the well-established norm of coverture that only fathers could transmit status. ${ }^{83}$ This clarification secured the proper

80. See id. In 1818, a South Carolina court gave the 1802 Act the latter interpretation: "[A]lthough it is apparent, that the child or children of a citizen mother, by an alien father, cannot inherit, yet, the converse of the rule is expressly admitted by the proviso...." Davis v. Hall, 10 S.C.L. (1 Nott \& McC.) 292, 294 (Const. Ct. App. 1818).

81. American citizenship law remained silent on the status of nonmarital children until the enactment of the Nationality Act of 1940 , ch. 876, $\$ \$ 201,205,54$ Stat. 1137, 1138-40.

82. Act of Feb. 10, 1855, ch. 71, $\S 1,10$ Stat. 604, 604 (emphasis added).

83. See Horace Binney, The Alienigenae of the United States, 2 AM. L. REG. 193, 202-07 (1854) (discussing the norm that only fathers could transmit citizenship). The patrilincal norm of coverture informed citizenship law until the law was amended by statute in 1934. See EDwIN BORCHARD, THE DIPLOMATIC PROTECTION OF CITIZENS ABROAD 612 (1915) ("[U]nder $\$ 1993$ of the Revised Statutes citizenship is not inherited through women."); CHARLES MAXSON, CITIZENSHIP 83 (1930) ("Nationality is not inherited through women, according to our law."): 3 JOHN BASSETT MOORE, A DIGEST OF INTERNATIONAL LAW § 374, at 285 (1906) ("Under $\$ 1993$ nationality is not inherited through women ...."); SECKLER-HUDSON, supra note 76, at 205-11: id. at 215 ("An American woman may go abroad and marry an alien who is stateless or of unknown nationality. If a child is born of this marriage, his nationality does not, under the laws of the United States follow that of the mother."); VAN DYNE, supra note 76. at 32 (discussing the norm that American citizenship is transmitted through fathers, not mothers): Lester B. Orfield, 
transmission of property-a pressing concern of several states ${ }^{8 s}$-and ensured that citizenship law would conform to coverture's basic principle of patrilineal property and status transmission in marriage.

Second, Congress pronounced that all foreign wives of American husbands would become American citizens simply by virtue of their marriage to American men. ${ }^{85}$ Contemporaries thought this alteration important because it ensured that children born abroad would gain citizenship only if both parents were American citizens, ${ }^{86}$ while also maintaining the patrilineal nature of jus sanguinis: Men effectively transmitted citizenship to their alien wives and foreign-born marital children.$^{87}$ The primary advocate of this change, Representative Cutting of New York, justified the change in terms of coverture: "[B]y the act of marriage itself the political character of the wife shall at once conform to the political character of the husband." ${ }^{88}$ Cutting assured his fellow congressmen that "there can be no objection to" such a law precisely because women "possess no political rights" of their own. ${ }^{89}$ As historian Nancy Cott has argued, through the 1855 Act Congress "rais[ed] the doctrine of coverture to the level of national identity" by empowering citizen husbands to convey citizenship to their non-American wives. ${ }^{\text {o }}$

After Congress passed the 1855 Act, judges were faced with cases in which American women married alien men-the reverse of the situation anticipated by the statute. If the logic of coverture applied to marriages between male citizens and their alien wives, judges asked whether such

The Citizenship Act of 1934, 2 U. CHI. L. REV. 99, 101 (1934) (stating that under the pre-1934 law, only fathers could transmit citizenship).

84. See, e.g., CONG. GLOBE, 33d Cong., 1st Sess. 170 (1854) (statement of Rep. Cutting). Representative Francis Cutting described how New York had altered inheritance laws in cases of children born abroad to accommodate the ambiguity of the 1802 Act. Cutting sought the revisions in order to make citizenship laws clearer for purposes of propenty transmission. See id.; see also Binney, supra note 83, at 210; Coth, supra note 54, at 1457.

85. See $§ 2,10$ Stat. at 604 .

86. Because citizenship could pass through fathers only, the forcign-bom child of an American woman and a foreign husband would not acquire the mother's citizenship. Under the 1855 Act foreign women were automatically naturalized upon marriage; thus, children of married American fathers necessarily had two American parents. Undivided nationality of the family was important to "the education of the children in allegiance, fidelity, and love of the government." 3 JOHN BASSETT MOORE, HISTORY AND DIGEST OF THE INTERNATIONAL ARBITRATIONS TO WHICH THE UNITED STATES HAS BEEN A PARTY 2499 (Washington, D.C.. 1898) (quoting the case of Elise Lebret, a French woman who contested being naturalized as an American upon marriage to an American citizen); see also CONG. GLOBE, 33d Cong.. Ist Sess. 170 (statement of Rep. Cutting) (comparing the proposed bill to a similar English law that enabled the newly made English wife to "at once inculcate in the minds of her children those principles of that country to whose political fortunes she has become united").

87. See BREDBENNER, supra note 54, at 21-22.

88. CONG. GLOBE, 33d Cong., Ist Sess. 170 (statement of Rep. Cutting). For an additional discussion of Cutting's statements in Congress, see Cott, supra note 54, at 1456.

89. CONG. GLOBE, 33d Cong., 1st Sess. 170 (statement of Rep. Cutting).

90. Cott, supra note 54, at 1457. 
logic also applied when an American woman married a foreigner. Reading the norms of coverture into the Act in 1883, a federal court in Peguignot $v$. Detroit" held that it did, noting "that legislation upon the subject of naturalization is constantly advancing towards the idea that the husband, as the head of the family, is to be considered its political representative,... and that the wife and minor children owe their allegiance to the same sovereign power." ${ }^{92}$ Congress confirmed the Peguignot court's covertureinspired reading of the 1855 Act in the Expatriation Act of 1907, which resolved that "any American woman who marries a foreigner shall take the nationality of her husband." ${ }^{93}$ When the Act was challenged in 1915 by a California suffragist who lost her citizenship (and state voting rights) after marrying a British citizen, the United States Supreme Court upheld its constitutionality, reasoning that the "ancient principle" of " $[t]$ he identity of husband and wife" (the "merger" doctrine of coverture) justified the result. ${ }^{94}$

Although it may be the case, as historian Candice Bredbenner has argued, that Congress did not pass the Expatriation Act of 1907 with the purpose of "reviv[ing] the dying legal concept of coverture," 95 coverture provided the unchallenged background rules against which the Expatriation Act and other citizenship statutes were written and interpreted. Thus, Representative Cutting could endorse the Act of 1855 by reminding his fellow congressmen that married women had "no political rights," ${ }^{96}$ and the Court could justify a woman's loss of citizenship and voting rights in the name of marital "unity." 97 While the incorporation of coverture into citizenship law achieved other policy goals (streamlining property transmission, cultural indoctrination of children, and marital unity), the use of coverture as the guiding hermeneutic in citizenship transmission between husband and wife cut against growing support for and recognition of women's claim to equal rights-parental, political, and civil. As demonstrated below, a similar logic reigned when legislators, judges, and immigration officials interpreted the laws regulating citizenship transmission from parents to children in and out of marriage. Coverture's norms were complied with, not with the intention of compromising

91. 16 F. 211 (C.C.E.D. Mich. 1883).

92. Id. at 216 (citing as evidence the 1802 and 1855 acts). In Comitis v. Parkerson. 56 F. 556 (C.C.E.D. La. 1893), the court followed the earlier Supreme Court decision in Shanks v. Dupont. 28 U.S. (3 Pet.) 242 (1830), in which the Court held that a woman did not lose her citizenship upon marriage to an alien. However, the Shanks holding was based on the then-operative legal principle that there was no right of expatriation without consent of the government, rather than on a failure to recognize marital unity. See Shanks, 28 U.S. at 245.

93. Expatriation Act of 1907, ch. 2534, § 3, 34 Stat. 1228, 1228.

94. Mackenzie v. Hare, 239 U.S. 299, 311 (1915).

95. BREDBENNER, supra note 54 , at 56 .

96. CONG. GLOBE, 33d Cong., 1st Sess. 170 (1854) (statement of Rep. Cutting).

97. Mackenzie, 239 U.S. at 311. 
women's emerging claim to equality, but to achieve other policy goals despite their impact on women's rights.

\section{Nonmarital Children and Citizenship}

If historians have described how citizenship laws incorporated coverture's limitation on citizenship transmission to foreign-born children of married citizen fathers and mothers, they have provided little guidance for twentieth-century jurists attempting to understand citizenship law's treatment of nonmarital children. Moreover, as Justice Ginsburg recognized in her dissent in Miller, the nineteenth-century citizenship statutes lack any mention whatsoever of foreign-born nonmarital children. ${ }^{98}$ Confronted with this silence, Justice Ginsburg interpreted the statutory language concerning "fathers" in early citizenship laws to mean that unwed fathers had the right to transmit citizenship, while unwed mothers did not. ${ }^{99}$ When those statutes are appraised within a larger context of institutional policies and practices, however, it is evident that the foreign-born nonmarital child's citizenship was determined according to parental marital status and sex, pursuant to the principles of coverture. ${ }^{100}$ According to the limited available sources, although some nineteenth-century immigration officials treated nonmarital children as nullius filius even with regard to inheritance of the mother's citizenship, ${ }^{101}$ by the early 1900 s nonmarital children were able to inherit citizenship from their mothers. ${ }^{102}$ At no time were American fathers able to transmit citizenship to nonmarital children without first "legitimating" them. In marriage, the scenario was reversed: Married mothers were completely barred from transmitting citizenship to their children until 1934 , while married fathers have always had a virtually unfettered right to do so.

When the issue of the citizenship status of foreign-born nonmarital children of American fathers came before the Maryland Supreme Court in 1864 in Guyer $v$. Smith, ${ }^{103}$ the court applied traditional common-law

98. See Miller v. Albright, 523 U.S. 420, 462 (1998) (Ginsburg. J., dissenting).

99. See id. (citing Guyer v. Smith, 22 Md. 239 (1864)).

100. See supra Section II.A.

101. See Acosta y Foster v. Spain (1871), reporned in 3 MOORE, supra note 86, at 2462-63 (expressing the opinion that the foreign-born child of an unwed American woman living in Cuba is not an American citizen).

102. See SECKLER-HUDSON, supra note 76, at 218-19; VAN DYNE, supra note 76, at 49-50 ("Illegitimate children follow the status of the mother ..." (citing a letler of March 27, 1903. from Assistant Secretary Pierce to Consul at Shanghai)); Orfield. supra note 83 at 105 (citing a State Department memo of October 27, 1932). This practice was rocognized as official policy by the State Department at least as early as 1912. See HOUSE COMM. ON IMIMIIGRATION \& NATURALIZATION, 76TH CONG., REPORT PROPOSING A REVISION AND CODIFICATION OF THE NATIONALTTY LAWS OF THE UNITED STATES, PART ONE: PROPOSED CODE WTTH EXPLANATORY COMMENTS 18 (Comm. Print 1939) [hereinafter PROPOSED CODE].

103. $22 \mathrm{Md} .239$. 
reasoning. It concluded that the 1802 Act simply did not apply to an American father's nonmarital foreign-born children because men generally did not transmit status outside marriage. John Guyer's two nonmarital sons-his named heirs-were to inherit a significant amount of land in Maryland. Articulating the basic principle of parent-child status transmission as determined by coverture, the court maintained that the Guyer sons were illegitimate under the laws of Maryland and thus were not citizens under the 1802 Act and could not inherit the property:

That Act declares, "that the children of persons who are, or have been citizens of the United States, shall, though born out of the limits and jurisdiction of the United States, be considered as citizens of the United States." These appellants claim the benefit of that section, as the children of John Guyer, who was a citizen of the United States. But the proof shows that they were not born in lawful wedlock, they are therefore illegitimate; under our law nullius filii, and clearly therefore not within the provisions of the Act .... ${ }^{104}$

The Guyer court's interpretation of the Act of 1802 became the authoritative interpretation of federal citizenship law as it applied to nonmarital children of American men for almost a century ${ }^{105}$ until the citizenship statute was altered in the Nationality Act of 1940 (the precursor to $\S 1409$ ) to give fathers a qualified right to transmit citizenship to foreignborn nonmarital children. ${ }^{106}$ While there were instances prior to 1940 in which fathers who had "legitimated" their nonmarital children (usually by marrying the mother) transmitted citizenship, ${ }^{107}$ federal statutes of the nineteenth and early twentieth centuries providing for a "father's" ability to transmit citizenship generally applied to married fathers only.

104. Id. at 249.

105. See BORCHARD, supra note 83 , at 612 \& n.6 (citing Guyer for the general principle that nonmarital children do not inherit citizenship through the father because "the illegitimate child is filius nullius and presumed to have no father"); SECKLER-HUDSON, supra note 76, at 220 \& n.74 (same). Given Guyer's conformity with the common law, and its wide support in the literature, it is not surprising that case law generally follows the Guyer rule. See, e.g., Louie Wah You v. Nagle, 27 F.2d 573 (9th Cir. 1928) (holding that where there is insufficient proof of legitimation. a foreign-born nonmarital child of an American father cannot inherit citizenship through the father); Ng Suey Hi v. Weedin, 21 F.2d 801, 802 (9th Cir. 1927) ("Illegitimate children, born abroad of citizens, being nullius filii, are not within the contemplation of section 1993 of the United States Revised Statutes, and hence are not themselves citizens." (citation omitted)). For cases in which legitimation had occurred, therefore allowing the father to transmit citizenship under the Guyer rule, see Dale v. Invin, 78 Ill. 170 (1875); and Compagnie Generale Transatlantique v. United States, 78 F. Supp. 797,799 (Ct. Cl. 1948), which noted that the Act of 1934 did not contemplate "the common law illegitimate, the nullius filius," but that it did extend to children who had been legitimated by the father.

106. See Nationality Act of 1940, ch. 876, $\S \S 201-205,54$ Stat. 1137, 1138-40.

107. See BORCHARD, supra note 83, at 613; SECKLER-HUDSON, supra note 76 , at 223 \& n.84. 
Given that, fathers of nonmarital children, unlike fathers of marital children, had no automatic right to transmit citizenship in the pre-1940 period, it is appropriate to reconsider the concerns animating citizenship law's gendered operation. Justice Ginsburg reasoned in Miller that, because the statutes indicated that "fathers" of foreign-born children could legally transmit citizenship, the right extended to all fathers of children born abroad-including unwed fathers. Under this historical gloss, § 1409 would have been a departure from a father-privileging norm in that it would have limited the father-child relationship and favored that of the mother and child. ${ }^{108}$ While this interpretation is correct at the level of statutory text, an expanded understanding of how citizenship law was interpreted within the norms of coverture suggests that, in practice, the law favored only the "legitimate" father-child relationship. Historically, as today, a father's marital status determined his ability to transmit citizenship. The policy rationales that animated this limitation advanced the interests of unwed fathers and government. Limitations on citizenship transmission outside marriage protected men from claims on property, support, and status by foreign-born nonmarital children. ${ }^{109}$ Moreover, the limitations on men's ability to transmit citizenship in the nonmarital context enabled legislatures to achieve various policy goals, such as limitation of immigration, protection of welfare coffers, ${ }^{100}$ and implementation of race-based immigration ${ }^{111}$ and property laws. ${ }^{112}$

The significance of allocating parental responsibilities on the basis of parental sex and marital status becomes more apparent when we consider women's ability to transmit citizenship in the nineteenth and early twentieth centuries. Justice Ginsburg was correct in arguing that until the enactment of the Act of 1934 and the Nationality Act of 1940, all women (married and unmarried) were deprived of the statutory right to transmit citizenship. ${ }^{113}$

108. See Miller v. Albright, 523 U.S. 420, 460-62 (1998) (Ginsburg, J., dissenting).

109. Most cases filed under the citizenship statute involved claims on property by nonmarital children.

110. See Neuman, supra note 75, at 1846-59; see also Miller, 523 U.S. at 432 n.9 (Stevens, J., plurality opinion) (noting that one explanation for the limitations on fathers' right to transmit citizenship is to minimize the financial burden on the states).

111. For a discussion of the racial logic of American citizenship law, see LAN F. HANEY LÓPEZ, WHTTE BY LAW: THE LEGAL CONSTRUCTION OF RACE 46-47 (1996). See also BORCHARD, supra note 83 at 612 (stating that, because foreign-bom nonmarital children of American fathers cannot inherit American citizenship. "it seems clear that illegitimnte half-castes born in semi-barbarous countries of American fathers and native women are not American citizens"); Cott, supra note 54, at 1465-71 (discussing the intersection of marriage law and racial classifications in citizenship law).

112. For example, in Guyer, the Maryland Supreme Cour cited the fact that the Guyer brothers' "mother is partly of African blood or descent" in finding that they were ineligible for citizenship and therefore unable to inherit John Guyer's property. Guyer v. Smith. 22 Md. 239. 246 (1864).

113. See Miller, 523 U.S. at 463 (Ginsburg, J., dissenting). Justice Ginsburg cited a 1939 opinion by the Attomey General questioning the right of unmarried women to transmit citizenship 
However, just as coverture's determination that nonmarital children were legally parentless had been softened in America ${ }^{1 / 4}$-enabling women to pass their status to nonmarital children-in practice, even prior to the enactment of the 1934 and 1940 citizenship statutes, unmarried women were allowed to transmit citizenship to their foreign-born children. ${ }^{115}$ As one contemporary source explained in 1934, "Under the old [pre-1934] practice a child born abroad of an unmarried American mother acquired American citizenship, though strictly this seemed to conflict with the statutory rule of descent through the father." ${ }^{116}$ Given this practice, neither the 1934 Act nor the Nationality Act of 1940 dramatically changed an unwed mother's ability to transmit citizenship-nor her underlying obligation to assume parental responsibility. Moreover, neither act significantly altered the ability (or responsibility) of a father to transmit citizenship.

The history of American citizenship law suggests that sex-based regulation of citizenship transmission was animated neither by an understanding of the mother's unique physiological role in childbirth nor by her purported choice to assume parental responsibility. Rather, the laws regulating citizenship transmission were shaped by the basic principles of coverture, as well as by coverture's normative commitments regarding

to foreign-born nonmarital children. See id. (citing 39 Op. Att'y Gen. 397, 398 (1939)). There is reason to believe that this was an unusual position. In the late 1930s, Congress was in the process of standardizing all the citizenship laws into one uniform statute. Thus, the opinion Justice Ginsburg cites doubting the legality of citizenship transmission by unwed mothers may have been part of an effort to identify vagaries in the citizenship statutes. Five months earlier, the same Attorney General acknowledged the State Department's practice of allowing women to enter the United States with illegitimate children, but maintained that the status of such children was unclear and that "additional legislation [was] desirable." 39 Op. Att'y Gen. 290, 291 (1939). Indeed, Justice Ginsburg recognized that for a time "the State Department permitted the transmission of citizenship from unwed mother to child." Miller, 523 U.S. at 463 (Ginsburg. J., dissenting) (citing PROPOSED CODE, supra note 102, at 18). When pressed to make a determination, the Attorney General interpreted the statute literally and maintained that under pre1934 law, such children were not citizens. See 39 Op. Att'y Gen. 397, 397 (1939).

Other sources reveal that citizenship transmission from the unwed mother to the forcign-born child was broadly recognized. See SECKLER-HUDSON, supra note 76, at 218 (noting that despite the vague policy on the matter, "the Department of State has on a number of occasions extended protection" to foreign-born nonmarital children of American women). Under the standards of international law, citizenship of a nonmarital child bom to an American mother abroad followed that of the mother. See VAN DYNE, supra note 76, at 49 ("The nationality of an illegitimate child born to an American mother would, by the law of nations, follow that of the mother."). As discussed infra Section II.C, this was also the common understanding of lobbyists and Congressmen when feminists challenged the policy as sex-discriminatory against mothers in the 1930 s.

114. See supra note 67 and accompanying text.

115. See SECKLER-HUDSON, supra note 76, at 218; Orfield, supra note 83, at 105.

116. Orfield, supra note 83 , at 105 n.21. Strictly speaking, the 1934 Act gave only marricd women the right to transmit citizenship to foreign-born children. given that a bill containing a provision for nonmarital children was considered and rejected by Congress. For a discussion of that provision, and its ultimate rejection, see infra Section II.C. 
parental responsibility. Women bore responsibility for nonmarital children, while fathers did not, and citizenship transmission followed that default allocation of parental responsibility. Moreover, women's responsibility for nonmarital children did not simply derive from social custom: Women had (and continue to have) a legal duty to care for children born out of wedlock, while men did (and do) not, a point uncritically made in both the government's brief and Justice Stevens's opinion in Miller. ${ }^{117}$ As I discuss below, it was this sex-based allocation of legal parental responsibility to which feminists of the 1930s objected when they battled in Congress to purge coverture from the citizenship laws. This same underlying legal allocation of maternal responsibility remains a source of unexamined gender injustice in the current citizenship regime.

TABLE 2. TRANSMISSION OF CITIZENSHIP ACCORDING TO PARENTAL SEX AND MARITAL STATUS IN THE NINETEENTH AND EARLY TWENTIETH CENTURIES

\begin{tabular}{|c|l|l|}
\hline & \multicolumn{1}{|c|}{ American Men } & \multicolumn{1}{c|}{ American Women } \\
\hline$\because$ & $\begin{array}{l}\text { Right to transmit } \\
\text { citizenship to foreign-born } \\
\text { children. } \\
\text { Right to transmit } \\
\text { citizenship to alien wife. }\end{array}$ & $\begin{array}{l}\text { No right to transmit } \\
\text { citizenship to foreign-bor } \\
\text { children. } \\
\text { Loss of citizenship upon } \\
\text { marriage to alien man. }\end{array}$ \\
\hdashline & $\begin{array}{l}\text { No right to transmit } \\
\text { citizenship to foreign-born } \\
\text { children, unless } \\
\text { "legitimated." } \\
\text { Not Married } \\
\text { children. }\end{array}$ & $\begin{array}{l}\text { According to policy } \\
\text { statements, could transmit } \\
\text { citizenship status to } \\
\text { foreign-bom children. } \\
\text { Common-law duty to } \\
\text { support children. }\end{array}$ \\
\hline
\end{tabular}

\section{Reform Efforts by Feminists of the 1930s}

Reviewing the congressional hearings during which feminists attempted to equalize men's and women's ability to transmit citizenship to nonmarital children serves two functions. First, it introduces previously unexamined primary sources demonstrating that, historically, unwed mothers could transmit citizenship to foreign-born children, while unwed fathers had only limited rights and correspondingly limited responsibilities. Second, these debates confirm that the sex-based regulation of citizenship transmission from parent to child was informed by normative concerns similar to those

117. See Miller, 523 U.S. at 443 (Stevens, J., plurality opinion) (describing the birth of a child as creating a "legal relationship" between the mother and child): Brief for the Respondent at 25-26, Miller (No. 96-1060) (arguing at length that the terms of $\$ 1409$ help "to cnsure that the child ... is actually comparably situated to one claiming through a citizen mother, who would be subject to the legal enforcement of parental obligations"). 
that animated coverture's regulation of parental responsibility in the nonmarital context-namely, protecting men from the liabilities of unwed parenthood and from claims to property and status by nonmarital children.

According to feminist supporter Senator John Cable, for centuries "male legislatures and jurists" had used America's "grossly unjust" citizenship laws to "jealously preserve[] the husband's dominance and limit[] the wife to a negligible sphere of activity and assign[] her to an inconspicuous position in the eyes of the law." 118 Recognizing this fact, the National Women's Party (NWP) and other women's organizations prioritized reform of American citizenship laws following the ratification of the Nineteenth Amendment in 1920. The Married Women's Independent Citizenship Act of $1922,{ }^{119}$ or the "Cable Act," was the result of the first successful effort by women's organizations to purge federal citizenship law of coverture by equalizing married women's citizenship status. The Cable Act repealed the Expatriation Act of 1907: An American woman no longer lost her citizenship upon marriage to an alien. ${ }^{120}$

Led by Burnita Shelton Matthews of the NWP, women's organizations next attacked sex-based regulations that governed citizenship transfer to foreign-born children of Americans. While much of the lobbying focused on married women's inability to transmit citizenship, the NWP fully recognized the law's disparate treatment of unmarried men and women. Congressional debates in the 1920s and 1930s reveal that feminists and legislators of the era recognized that coverture informed jus sanguinis, and that, as applied to unmarried parents, citizenship laws presumed and reinforced a gendered allocation of legal parental responsibility. Feminist lobbyists insisted that equalizing unmarried fathers' and mothers' abilities to transmit citizenship would help remedy coverture's inequitable allocation of full responsibility for nonmarital children to women. Despite any vagueness in the letter of the law concerning the citizenship status of nonmarital children of American women, ${ }^{121}$ women's organizations and legislators in the early 1930s recognized that it was standard practice to allow unmarried women to convey citizenship to their foreign-born children. ${ }^{122}$ Understanding that unmarried women's practical right to transmit citizenship to foreign-born children was predicated upon their legal responsibility to assume full financial and caregiving duties, feminists argued that this sex-based policy disadvantaged American women relative

118. American Citizenship Rights of Women: Hearing on S. 992, S. 2760, S. 3968, and S. 4169, Before a Subcomm. of the Comm. on Immigration, 72d Cong. 25-26 (1933).

119. Ch. 411, $\S 3,6-7,42$ Stat. 1021, 1022, repealing Expatriation Act of 1907. ch. 2534. $\S 3,34$ Stat. 1228,1228 .

120. See id.

121. See supra note 116 and accompanying text.

122. See infra text accompanying notes 125-130. 
to American men by perpetuating the sex-based allocation of parental duties.

Debated in committee from 1930 to 1933, proposed section 1993 of the Amendment to the Women's Citizenship Act of 1922 would have been the first federal statute to address explicitly the citizenship status of foreignborn nonmarital children of American citizens:

Any child, whether legitimate or illegitimate, born out of the limits and jurisdiction of the United States, whose father or mother may be at the time of the birth of such child a citizen of the United States, is declared to be a citizen of the United States; but the right of citizenship shall not descend to any child whose father or mother had never resided in the United States previous to the birth of such child. $^{123}$

Although the final form of the Act of May 24, 1934, omitted the phrase "whether legitimate or illegitimate," 124 the debates over patrilineal citizenship transmission to nonmarital children reveal the gendered conception of parental rights and responsibilities from which feminists and congressmen alike reasoned. Modern equal protection analysis of $\S 1409$ recognizes the truncation of the father's rights as the only plausible gender-based injury, as demonstrated by the plurality and dissenting opinions in Miller. But in the 1930s, virtually all of the committee members considering section 1993 understood that, without the proposed amendment, the law disadvantaged unwed mothers by enabling unwed fathers to avoid responsibility. ${ }^{125}$

When Matthews testified before the House Committee on Immigration and Naturalization in 1932, she-and her audience of Representativesassumed that equalizing the law concerning the transmission of citizenship to nonmarital children would help equalize parental responsibility:

Mrs. Matthews: ... The second point [of the bill] deals with illegitimate children. Under the law at the present time, the only child to whom a mother is permitted to transmit her nationality is an illegitimate child. As a rule the father is given superior rights over the legitimate child and the mother has little or no authority, but when it comes to the illegitimate child, which is a great burden,

123. Amendment to the Women's Citizenship Act of 1922, and for Other Purposes: Hearings on H.R. 14684 Before the House Comm. on Immigration and Naturalizarion, 71 st Cong. 1 (1930) [hereinafter Hearings on H.R. 14684] (emphasis added).

124. Act of May 24, 1934, ch. 344,48 Stat. 797.

125. This understanding of the gender injustice caused by $\S 1409$ is raised only briefly by Justice Ginsburg in Miller, and remains obfuscated under modem equal protection analysis. See Miller v. Albright, 523 U.S. 420, 468 (Ginsburg, J., dissenting). 
then the mother is the only recognized parent and the father is put safely in the background.

The Chairman: You point out that they both ought to carry the burden.

Mrs. Matthews: Exactly. ${ }^{126}$

Congressmen present at the hearing had very little problem understanding Matthews's basic proposition: "This witness," the Chairman of the committee reiterated, "wants the burden to be carried by both the father and the mother, without excluding the father." 127 An exchange between Congressman Rutherford and Senator Cable reveals the shared perception of the injustice caused by the unamended law:

Mr. Cable: I think everybody understands that there is certain discrimination against the mother and in favor of the father.

Mr. Rutherford: Let us cure that. I want to take some of these rights from the men. I would equalize these matters between the men and the women, but I would take some of those rights from the men. I want to cure these inequalities. ${ }^{128}$

Significantly, it was the committee member opposed to equalizing legal parent-child relationships, Representative Jenkins, who portrayed the statute's exclusive recognition of the mother-child relationship in the nonmarital context as a female-privileging policy. At a committee hearing regarding the proposed citizenship reform, Jenkins suggested to witness Laura Berrien of the National Association of Women Lawyers that, if Congress were to equalize the position of men and women with respect to nonmarital children, it would (or should) deny unmarried women the right of transmission altogether:

Mr. Jenkins: At the present time a poor little illegitimate child is born in some foreign country. The only protection he gets is because he has a mother who is an American citizen, and she can bring him in. He ought to be brought in; he has no other place to stay. If you pass section 5 [of the bill] that poor little illegitimate will have no chance. You take it from the mother. You equalize the

126. Relating to Naturalization and Citizenship Status of Certain Children of Mothers Who Are Citizens of the United States, and Relating to the Removal of Certain Distinctions in Matters of Nationality: Hearings on H.R. 5489 Before the House Comm. on Immigration and Naturalization, 72d Cong. 3 (1932) [hereinafter Hearings on H.R. 5489].

127. Id. at 5 .

128. Hearings on H.R. 14684, supra note 123, at 10 (emphasis added). 
mother with the father, the mother can't bring him in and the father can't bring him in. ${ }^{129}$

Unflustered by Jenkins's suggested resolution, Berrien simply responded that "it will be up to Congress to equalize in the way it seems best." 130

Jenkins was convinced that allowing citizenship to pass through men to nonmarital children would insult common-law tradition and policy. He argued, in sum, that citizenship transmission through the unmarried mother was an exception to the general norm that nonmarital children were legally parentless. The common-law origins of Jenkins's resistance to the proposed changes become even clearer upon analysis of his exchange with Burnita Shelton Matthews. Jenkins argued that the current law-which allowed women but not men to transmit citizenship to nonmarital children-was " a great recognition of the American woman.... If she is unfortunate [pregnant and unmarried], and her citizenship is American and the father is uncertain, that is a great boon." 131 When Matthews argued that the law actually favored the American father by "permit[ting] him to escape the burdens incident to illegitimate parenthood," 132 Jenkins responded by calling attention to the evidentiary problems involved ${ }^{133}$ and by citing the principles of coverture that governed inheritance: "The child cannot inherit. It would not do, if he could. You are trying to undo what practically all of the big States in the country have held to be the proper procedure (to give to this child consideration)...."134 Jenkins's defense of common-law reasoning suggests that he could not, or would not, imagine a world in which men assumed equal responsibility for nonmarital children. Moreover, his exchanges with Berrien and Matthews suggest that he was concerned not only with the transmission of citizenship status, but with an entire set of benefits that flowed from the recognition of the father-child relationship. He was, in other words, concerned about the dilution of coverture's rules of property and status transmission that informed citizenship law and protected unmarried fathers from unwanted liability.

In 1934, Congress amended the Cable Act to enable married mothers to transmit citizenship to their foreign-born children, but failed to resolve explicitly the status of foreign-born nonmarital children. Instead, the

129. Hearings on H.R. 5489, supra note 126, at 17 (statement of Rep. Jenkins). In Miller, Justice Scalia reasoned in a similar fashion when he argued that, because of severability problems, the "proper" solution to a purported equal protection violation in $\$ 1409$ is to "deny[ ] naturalization of illegitimate children entirely." Miller, 523 U.S. al 459 (Scaliz. J., concurring in the judgment).

130. Hearings on H.R. 5489, supra note 126, at 17 (statement of Laura M. Berrien).

131. Id. at 5 (statement of Rep. Jenkins).

132. Id. (statement of Bumita Shelton Matthews).

133. See id. (statement of Rep. Jenkins) ("The father of an illegitimate child is uncertain.").

134. Id. 
amendment simply provided that a foreign-born child whose "father or mother or both ... is a citizen of the United States, is declared to be a citizen of the United States." 135 Six years later Congress clarified the ambiguities of the 1934 Act with the comprehensive Nationality Act of 1940, which provided explicitly for the transmission of citizenship to nonmarital children. The Act allowed nonmarital children of citizen fathers to "inherit" American citizenship if the father "legitimated" the child prior to majority; no such procedure was required of unmarried citizen mothers. ${ }^{136}$ While the NWP lobbyists' efforts in Congress successfully purged citizenship law of coverture's rules and norms as they applied to married women and their children, the battle over the transmission of citizenship to nonmarital children was less successful. The relationship of fathers and their foreign-born nonmarital children would be recognized for citizenship purposes on a very limited basis, and in a manner that enabled fathers to control the terms of the legal relationship. Mothers, on the other hand, transmitted citizenship to nonmarital children virtually by default. ${ }^{137}$

Seen from this perspective, and contrary to Justice Ginsburg's analysis of the statutory history, the Nationality Act of 1940 had little impact in this narrow area of citizenship transmission. The foreign-born nonmarital child of an American father had no claim to citizenship, unless the father chose to confer it upon her, just as she had no automatic claim to paternal support. Conversely, the foreign-born nonmarital child of an American mother was automatically an American citizen and had a right to maternal support. In sum, the Nationality Act of 1940 effectively codified the coverture-inspired principles of the nineteenth and early twentieth centuries into federal statute. Those principles-and the legal allocation of maternal responsibility that they effect and perpetuate-remain part of our law today. ${ }^{138}$ In 1986, Congress increased the number of criteria for fathers of foreign-born nonmarital children, requiring production of "clear and convincing evidence" of paternity, legitimation of the child before she turned eighteen, and a promise to support the child until she turned eighteen. ${ }^{139}$ Insofar as the 1986 version of $\S 1409$ increased the legal barriers between a father and his nonmarital child, it entrenched coverture's sex-based allocation of parental rights and responsibilities.

135. Act of May 24, 1934, ch. 344,48 Stat. $797,797$.

136. See Nationality Act of 1940 , ch. 876, $\S \S 201-205,54$ Stat. 1137, 1138-40.

137. See supra note 25 for a discussion of the one-year U.S. residency requirement for unwed mothers.

138. Justice Ginsburg observed that the Nationality Act of 1940 provided the basic contours of citizenship law now embodied in $\S 1409$, but did not acknowledge the practical continuity between the pre- and post-1940 citizenship regimes. See Miller v. Albright, 523 U.S. 420, 466-68 (1998) (Ginsburg, J., dissenting).

139. See 8 U.S.C. $\$ 1409$ (a) \& note (1994). See supra note 5 for a summary of the statute. 


\section{RECONSIDERING MILLER AND UNWED FATHERHOOD}

In this Part, I revisit the Miller decision in light of the expanded history of citizenship and coverture, focusing on the legal allocation of parental responsibilities that this history invites. I contest Justice Stevens's determination that $\S 1409$ does not invoke the "gender equality principle" by calling attention to the ahistorical aspects of his interpretation and to the problematic ways in which the statute defers to paternal "choice" concerning whether to assume parental responsibilities. Given that citizenship law has long favored maternal responsibility for nonmarital children, I argue that $\S 1409$, and all other statutes that allocate parental rights and responsibilities on the basis of sex, should be subject to the heightened standard of scrutiny announced in Virginia. Considering Miller in the broader context of the Court's equal protection jurisprudence, I then briefly explain why even under the Virginia standard-with its keen distrust of stereotypes and generalizations-the structure of laws regulating parenting and reproduction effectively insulates the sex-based allocation of parental rights and duties from meaningful analysis.

\section{A. Maternal Responsibility, Paternal Choice}

One of Justice Stevens's chief explanations for why $\S 1409$ does not invoke the "equality principle" was that the statute purportedly allocates the right to transmit citizenship in response to the mother's unique physiological role in childbirth and her choice to give birth. ${ }^{1+0}$ Thus, he rationalized $\S 1409$ 's default allocation of parental rights to unwed mothers, reasoning from a strange conflation of biological determinism and voluntarism: Because women bear children and purportedly choose to do so (rather than abort), they are held solely responsible for children born out of wedlock. As a "reward" for this labor, they are given superior citizenship transmission rights. In response, Justices Breyer and Ginsburg argued that the statute actually rests on a stereotypical understanding of who cares for nonmarital children. They reasoned that because some fathers assume responsibility for nonmarital children and some mothers do not, $\S 1409$ is based on impermissible generalizations.

Perhaps the most obvious shortcoming of Justice Stevens's logic is the frailty of his claims regarding the legal significance of biological sex differences and "choice." Justice Stevens's analysis of biological difference and choice is itself riddled with gender-based assumptions. Although both men and women have physiological roles in reproduction, Justice Stevens reasoned that only the mother's role is legally relevant to

140. See supra Section I.A for a discussion of Justice Stevens's "choice" logic. 
the determination of default allocations of parental rights and responsibilities. Likewise, the only "choice" that is relevant to the default allocation of parental responsibilities is that which is made after conception and which can be made by the mother only: the choice of whether to terminate the pregnancy. Choices and conduct that precede conception and involve both prospective parents-such as whether to have sexual intercourse and whether to use birth control-are rendered irrelevant to the initial allocation of parental rights and responsibilities.

Placed in historical context, Justice Stevens's defense of $\$ 1409$ 's allocation of greater responsibility to mothers on the basis of maternal physiology and "choice" seems misplaced, if not ironic. It is simply ahistorical to argue that Congress deferred to women's reproductive choice, or even considered it, when it first enacted a statute recognizing unwed mothers' right to transmit citizenship: In 1940 abortion was illegal in most states, and contraception was banned or limited in many. ${ }^{141}$ More importantly, the history of citizenship transmission reveals that a very different kind of choice has informed the gendered allocation of parental responsibility: fathers' choice. The current citizenship regime recognizes that women are obligated by law to assume responsibility for a nonmarital child, and that fathers have a choice whether to assume that legal burden. Paternal "choice" - and the limitations placed on that discretion-have, in turn, been informed by a desire to maintain "legitimate" lines of inheritance and to protect men from unwanted paternal responsibilities. A woman's special physiological role in childbearing or her purported "choice" in becoming a mother or assuming parental responsibility has had little to do with citizenship transmission (as evidenced by the fact that neither married nor unmarried women could transmit citizenship by statutory right until 1934).

Evaluating $\S 1409$ from the standpoint of how it perpetuates a default allocation of maternal legal responsibility leads to an understanding of citizenship law quite distinct from that of Justice Stevens. Analyzing citizenship law with sensitivity to how it aggrandizes men's prerogatives in matters of parental responsibility is not typical under current equal protection jurisprudence, but such an approach is not wholly foreign to the federal judiciary. In 1991, a district court evaluated the operation of the Nationality Act of 1940 in LeBrun v. Thornburgh ${ }^{142}$ a case involving the nonmarital child of a World War II veteran. Employing an alternative approach to the intersection of citizenship, gender, and parental responsibility, Judge Sarokin observed that the Act "served to make the

141. See Rickie Solinger, Pregnancy and Power Before Roe v. Wade. 1950-1970, in ABORTION WARS: A HALF-CENTURY OF STRUGGle, 1950-2000, at 15, 17 (Rickie Solinger ed., 1998).

142. 777 F. Supp. 1204 (D.N.J. 1991). 
citizenship of children born out of wedlock to American fathers, particularly those serving in the armed forces, subject to the personal vagaries and consciences of their fathers": ${ }^{1+3}$

Those who have no choice in the marital state of their parents should not be so penalized or stigmatized, and their rights to citizenship should not be dependent on the moral fortitude (or lack thereof) of one of their parents. The unfairness is exacerbated by placing such power solely in the hands of the male parent. The law was thus discriminatory in its impact upon children born out of wedlock and sexist in making citizenship dependent upon the acquiescence of the male parent only. ${ }^{1+4}$

In stark contrast to Justice Stevens's claim that $\S 1409$ "rewards" a mother's "choice" to assume full parental responsibility, ${ }^{1 \text { s }}$ Judge Sarokin observed that the Nationality Act actually privileged the father's choice and facilitated abuse of that discretion. Like Burnita Shelton Matthews's observation that the reigning citizenship laws put "father[s] ... safely in the background," 146 Judge Sarokin's decision in LeBrun is sensitive to how $\S 1409$ operates as a source of sex discrimination by privileging male autonomy.

The contrast between Judge Sarokin's and Justice Stevens's understandings of the gender dynamics in $\S 1409$ is most visible in their differing views concerning citizenship transmission to "war babies" foreign-born nonmarital children of U.S. servicemen. Judge Sarokin recognized that the paternal prerogative afforded American men abroad, especially servicemen, functions as a source of sex-based discrimination. Apparently convinced during oral arguments that $\S 1409$ was animated by the war-baby problem, ${ }^{147}$ Justice Stevens viewed the disproportionate number of unwed fathers among U.S. servicemen stationed abroad as a convincing justification for the statute's use of sex-based classifications, rather than as a cause for consternation. Justice Stevens reasoned that the vast majority of children born abroad to U.S. soldiers are born to men, ${ }^{1+8}$ and that such men are especially unlikely to know-or even know abouttheir nonmarital children born abroad. Thus, according to this analysis, Congress has a legitimate interest in ensuring that such men have an

143. Id. at 1206.

144. Id.

145. Miller v. Albright, 523 U.S. 420, 433-34 (Sievens, J., plurality opinion).

146. Hearings on H.R. 5489, supra note 126, at 3.

147. See Transcript of Respondent's Oral Argument, Miller (No. 96-1060), available in 1997 WL 669809 , at *10-11.

148. See Miller, 523 U.S. at 439 (Stevens J., plurality opinion) (citing U.S. DEP'T OF COMMERCE, STATISTICAL ABSTRACT OF THE UNITED STATES 381 (99th $\mathrm{cd}$. 1978) for the number of U.S. soldiers stationed abroad in 1970). 
"opportunity to develop a meaningful relationship with their children" before enabling them to transmit citizenship. ${ }^{149}$ That a U.S. soldier-father may "abscond before his child has an opportunity to bond with him" 150 does not, Justice Stevens contended, minimize the importance of that interest, nor does it bear on how the government employs sex-based classifications to achieve that goal. Moreover, that the U.S. government often facilitates the circumstances in which servicemen become fathersfor example, by establishing "rest and recreation" facilities for servicemen abroad, where fraternization with local women is licensed and often subsidized ${ }^{151}$ - does not seem to bear on Justice Stevens's understanding of the gendered logic of the citizenship regime.

That such a regime favors male autonomy and perpetuates women's sole responsibility for nonmarital children is demonstrated by the consequences of $\S 1409$. A U.S. serviceman who fathers a child abroad, regardless of whether he knows of the child or has reason to suspect that he has fathered a child, often leaves the child and its mother to their own devices. Because the father is not legally responsible for the child's wellbeing, and because the child is not an American citizen, there are no repercussions for the father's actions. Although not always the case, the mother and the child are often left without adequate resources for support, a situation that typically leads to a severe diminution of standard of living, if not to poverty. ${ }^{152}$ Meanwhile, the American mother who bears a child abroad has legal responsibility for the child and incurs all the liabilities of single parenthood. By making it more difficult for citizenship to pass from the father to his foreign-born nonmarital child, default assignment of citizenship at birth according to parent sex and marital status perpetuates this basic allocation of parental responsibility. Children generally live with the parent from whom they inherit citizenship, an arrangement that under the current regime facilitates maternal, rather than paternal, caretaking.

Justice Stevens largely based his claim that $\S 1409$ neither invokes the "gender equality principle" nor results in gender-based injury on the fact that "mothering" and "fathering" involve biologically distinct relationships (and that those differences have legal salience). As the history of citizenship transmission demonstrates, however, the real differences

149. Id. at 440 .

150. Id.

151. See Kolby, supra note 1, at 63-65 (discussing the U.S. government's role in encouraging the growth of prostitution in Angeles City, just outside Clark Air Force Base, and Olongapo, next to Subic Bay Naval Stations, both in the Philippines). Some scholars have discussed Miller as a case concerning the human rights of the noncitizen mothers and children of American men. See Ranjana Natarajan, Amerasians and Gender-Based Equal Protection Under U.S. Citizenship Law, 30 Colum. Hum. RTS. L. Rev. 123 (1998); Debra L. Satinoff, Comment, Sex-Based Discrimination in U.S. Immigration Law: The High Court's Lost Opportunity To Bridge the Gap Between What We Say and What We Do, 47 AM. U. L. REV. 1353 (1998).

152. See Kolby, supra note 1, at 61-62. 
between men and women in reproduction do not adequately account for the disparate allocation of parental responsibility. Judicial skepticism is warranted even when the government distinguishes between men and women on the basis of "real" or "inherent" differences. Indeed, precisely because legislative bodies are most comfortable making sex-based distinctions where they detect "real" differences, judicial vigilance is required in order to ensure the realization of our "gender equality principle" even where men and women are biologically dissimilar. Such a conclusion comports with a familiar-but sometimes underappreciatedinterpretation of heightened scrutiny as a test used to "smoke out" illegitimate government purposes. ${ }^{153}$ Insofar as it reveals the sex-based stratification in unwed parenting that $\S 1409$ creates, an expanded historical understanding of citizenship transmission counsels that parenting-related laws should be examined with the same skeptical scrutiny given other statutes employing sex-based classifications: the heightened scrutiny announced by the Court in Virginia.

\section{B. Beyond Stereotypes: Default Rules and Equal Protection}

If focusing on duties in addition to rights helps determine the standard of scrutiny that courts should use when examining sex-based regulation of reproduction and parenting, it also raises a more profound doctrinal question: Can equal protection analysis in its current form-at any level of scrutiny-adequately reveal the discriminatory operation of sex-based parenting-related statutes? If Miller is any indication, it is not evident that even heightened scrutiny - focused exclusively on the allocation of parental rights-will necessarily reveal the gender-based harms that the concomitant allocation of responsibilities often effects. In Miller, Justice Stevens argued that $\S 1409$ is constitutional even under heightened scrutiny. ${ }^{154}$ And despite their use of heightened scrutiny, the dissenters in Miller attended only to the allocation of parental rights effected by $\S 1409$, leaving the underlying gendered allocation of legal parental responsibility largely unexamined. ${ }^{155}$ By focusing on the relationship between biological difference and the allocation of rights, the plurality and the dissenters failed to recognize that

153. See Richmond v. J.A. Croson Co., 488 U.S. 469. 493 (1989) (O'Connor, J., plurality opinion) ("[T]he purpose of strict scrutiny is to 'smoke out' illegitimate uses of race by assuring that the legislative body is pursuing a goal important enough to warmant use of a highly suspect tool."); see also JOHN HART ELY, DEMOCRACY AND DISTRUST 146 (1980) ("[F]unctionally. special scrutiny, in particular its demand for an essentially perfect fit, tums out to be a way of 'flushing out' unconstitutional motivation ...."); Jed Rubenfeld, Affimative Acrion, 107 YALE L.J. 427, 436-38 (1997) (arguing that the appropriate function of heightened scrutiny in constitutional analysis is to "smoke out" illegitimate state purposes).

154. See Miller, 523 U.S. at 434 n.11 (Stevens, J., plurality opinion).

155. Justice Ginsburg briefly intimated that the statute permits fathers of foreign-bom nonmarital children to "avoid responsibility." Id. at 470 (Ginsburg, J., dissenting). 
$\S 1409$ is part of a constellation of common-law rules and statutes that hold women, but not men, responsible for children born out of wedlock.

As presently configured, the equal protection test requires the government to demonstrate that a statute is intended to effect either a "reasonable" or a "substantial" legislative objective (depending on which standard of scrutiny the court employs), and that the relationship between the sex-based classification and the achievement of the purported objective is sufficiently proximate. ${ }^{156}$ Additionally, sex-based laws that assume or "rely on overbroad generalizations about the different talents, capacities, or preferences of males and females" ${ }^{157}$ are impermissible. There are two considerable problems with this method of analysis when applied to parenting-related statutes. First, the analysis leads to a circular justification of sex-based allocations of parental rights. The legal default rule that mothers assume parental responsibility for nonmarital children generally serves as the "reasonable" or "substantial" justification for a concomitant allocation of parental rights: ${ }^{158}$ One sex-based legal rule is used to justify another. The result of such circular reasoning in Miller, as in other equal protection cases involving the regulation of parenting and reproduction, is that parenting-related statutes are insulated from the searching judicial scrutiny that the modern equal protection doctrine purports to offer. As a consequence, equal protection analysis itself obfuscates the gender-based harms that result from such laws. A second, related problem is that by promoting a search for sex-based stereotypes (for example, that women tend to assume responsibility for nonmarital children), the current approach fails to detect the coercive nature of the default allocation of parental responsibility. ${ }^{159}$

Defending $§ 1409$ in Miller, the government argued, ${ }^{160}$ and Justice Stevens agreed, that a default rule of legal maternal responsibility exists (with the imprimatur of judicial approval), ${ }^{161}$ and that this rule justifies $\S 1409$ 's gender-based allocation of parental rights. ${ }^{162}$ Justice Stevens's method of analysis is by no means novel. The Court's application of the equal protection doctrine to other cases involving nonmarital fathers has yielded similar circular reasoning. For example, in Parham v. Hughes, ${ }^{163}$

156. See supra note 6 and accompanying text.

157. United States v. Virginia, 518 U.S. 515, 533 (1996).

158. See, e.g., supra note 20.

159. As a consequence, Justice Stevens uncritically argues that $\S 1409$ does not presume sex stereotypes, but rather that it is predicated on certain legal allocations of parental responsibility. See Miller, 523 U.S. at 440 (Stevens, J., plurality opinion).

160. See Brief for the Respondent at 25, Miller (No. 96-1060) (noting that states can enforce child-support obligations against unwed mothers on the basis of the Iegal relationship established at birth).

161. See Miller, 523 U.S. at 440-43 (Stevens, J., plurality opinion).

162. See id.

163. 441 U.S. 347 (1979). 
the Court upheld a Georgia statute that allows the mother, but not the father, of a nonmarital child to sue for the wrongful death of the child. The majority justified its position by arguing that under a separate state statute "only a father can by voluntary unilateral action... legitimate" the child. ${ }^{164}$ The majority failed to acknowledge, however, that the statutory regime required only the father to legitimate the child in order to exercise his parental rights-the mother was neither required nor able to legitimate her child and was the presumed caretaker parent. In a dissenting opinion, Justice White called attention to the "startling circularity" of the majority's argument, ${ }^{165}$ observing that "[i]t is anomalous, at least, to assert that sex discrimination in one statute is constitutionally invisible because it is tied to sex discrimination in another statute." 166 In Parham, while the wrongfuldeath statute did not literally allocate parental rights and responsibilities on the basis of sex, its reliance on a default rule of maternal responsibility (a presumption that could be overcome only if the father chose to legitimate the child using the legitimacy statute) effectively insulated the wrongfuldeath statute from review. The majority justified one gender-based law by pointing to another.

Likewise, Justice Stevens's circular reasoning in Miller insulated from judicial scrutiny both the legal default rule of maternal responsibility and the concomitant allocation of inferior paternal rights: Mothers assume parental responsibility by law and therefore have greater parental rights. The problem of circularity was compounded in Miller, where Justice Stevens rationalized use of a lower standard of scrutiny than is applied to most gender-based laws. Thus, the entire constellation of legal rules operating in Miller was subject only to rational review, an extremely deferential standard. One way to address this quandary is to require heightened scrutiny of parenting-related laws, and clearly that is the major focus of the current doctrinal debate. ${ }^{167}$ Given the failure of heightened scrutiny to detect how gender functions in the regulation of citizenship transmission, however, it is unclear that simply insisting on heightened scrutiny of all parenting-related statutes would lead to full recognition of the gender injustice at stake in statutes such as $\S 1409$. The problem with the current doctrine is not simply how closely courts look for statesponsored gender inequality, but also how they define gender discrimination in the regulation of parenting.

164. Id. at 355 .

165. Id. at 361 .

166. Id. at $362 \mathrm{n.2}$ (White, J., dissenting). This kind of circular logic is by no means limited to the parenting context. The Cour used similar reasoning to justify the constitutionality of the Military Services Act in Rostker v. Goldberg, 453 U.S. 57 (1981), when it held that the exclusion of women from draft-registration lists was justifiable because women were excluded from combat service.

167. See supra note 7 . 


\section{CONCLUSION: IF MOTHERS' RIGHTS WERE FATHERS' DUTIES}

How, then, should a court examine the distribution of legal parental responsibility that undergirds sex-based parenting-related statutes such as $\S 1409$ ? While a reevaluation of the current formalist approach to equal protection analysis is in order, a more modest approach may provide an interim remedy: When confronted with a statute that grants parental rights according to parental sex, courts should subject the default allocation of maternal responsibility to the same searching scrutiny that they give to sexbased allocations of parental rights. Is the statute predicated on a sex-based default allocation of parental responsibility? If so, is that default allocation itself justifiable, or is it based on an inequitable understanding of parental responsibility? In Miller, the government would have been required to justify why the state considers mothers, rather than fathers, to be the default providers for nonmarital children, and how that allocation of responsibility serves important government interests.

The government could have argued that the biological differences in reproduction justify sex-based allocations of legal parental responsibility (thereby justifying sex-differentiated parental rights). Such an assertion is vulnerable to the obvious retort that, were this a statutory regime that regulated on the basis of physiological difference, married citizen mothers would also have an ability superior to that of married citizen fathers to transmit citizenship. The government also could have argued that the United States has a substantial interest in limiting fathers' responsibility for foreign-born nonmarital children because American men are more likely than American women to become a parent while abroad. They might even have argued that the government has an interest in minimizing American fathers' liability in this manner because the U.S. military is so heavily involved in operations abroad. ${ }^{168}$ Exposing men to such liability would burden American servicemen and, perhaps by extension, the military itself. Finally, the government could have asserted an interest in preventing the immigration of tens of thousands of (largely poor) war babies and maintained that there are simply many more foreign-born nonmarital children of American men than of American women. ${ }^{169}$ While it is uncertain how a court would respond to these arguments, the male-privileging dimensions of such government objectives would be laid bare.

A court would certainly entertain countervailing objections of the sort raised by Justice Stevens in Miller, such as the concern that the foreignborn child or citizen parent demonstrate an affective bond between the child

168. For Justice Stevens's discussion of the war-baby problem, see Miller v. Albright, 523 U.S. 420, 439-41 (Stevens, J., plurality opinion).

169. See Kolby, supra note 1, at 61-62. 
and the United States, and the need to prevent fraudulent citizenship claims. ${ }^{170}$ While these concerns are important legislative goals, once the court recognized $\S 1409$ as a gender-based statute requiring heightened scrutiny, analysis of competing concerns would diverge significantly from Justice Stevens's analysis in Miller. For example, using rational basis review, Justice Stevens failed to inquire whether the evidentiary problems may be resolved by a less discriminatory means than the numerous requirements that $\S 1409$ imposes on fathers only: a promise of child support, ${ }^{171}$ "clear and convincing evidence of a blood relationship," ${ }^{172}$ and legitimation. ${ }^{173}$ Rather, he argued that Congress has discretion to determine the means by which paternity can be established. ${ }^{174}$ Given the ease with which paternity can be established using modern DNA testing, however, Justice Breyer maintained that under heightened scrutiny it is highly doubtful that the government could demonstrate that numerous statutory requirements are necessary to resolve evidentiary problems. ${ }^{175}$

Similarly, Justice Stevens argued that Congress "rationally" differentiated between men and women in $\S 1409$ because citizen mothers are more likely to develop affective bonds with their nonmarital children than are citizen fathers. ${ }^{176}$ This argument fails not simply because it relies on gender stereotypes, as Justices Breyer and Ginsburg contended in their dissenting opinions. ${ }^{177}$ It fails because the operation of $\S 1409$-providing default citizenship for children of citizen mothers, but not for citizen fathers-helps effectuate the very parenting relationship that Justice Stevens used to justify the statute's use of sex-based classifications: the mother-child bond. By limiting legal recognition of certain parent-child relationships, $\S 1409$ is a self-fulfilling prophecy. By assigning citizenship to children of citizens who have legal parental responsibility at birth (and who are all women), but not to the children of citizens who do not have legal parental responsibility at birth (and who are all men), the statute promotes arrangements in which children of American mothers, but not those of American fathers, will develop bonds with their citizen parents.

Focusing on allocations of parental responsibility, rather than considering allocations of parental rights in isolation, would also help remedy shortcomings of the equal protection analysis as employed by the dissenters in Miller-especially the current preoccupation with gender

170. See Miller, 523 U.S. at 440 (Stevens, J., plurality opinion).

171. See 8 U.S.C. § 1409(a)(3) (1994).

172. Id. $\$ 1409(\mathrm{a})(1)$.

173. See id. $\$ 1409$ (a)(4). Justice Stevens narrowed the scope of his review of $\$ 1409$ by analyzing the age requirement only. See Miller, 523 U.S. at 444 (Stevens, J., plurality opinion).

174. See Miller, 523 U.S. at 438 (Stevens, J., plurality opinion).

175. See id. at 484-85 (Breyer, J., dissenting).

176. See id. at 438 (Stevens, J., plurality opinion).

177. See id at 469 (Ginsburg, J., dissenting); id. at 482 (Breyer, J., dissenting). 
stereotypes. For example, Justice Breyer suggested that a gender-neutral regime- - one that allocates the right to transmit citizenship to foreign-born nonmarital children on the basis of "knowledge-of-birth" or primarycaretaker status-would remedy the gender injustice caused by $\S 1409 .{ }^{178}$ However, once we recognize that $\S 1409$ is undergirded by a system of sexbased legal allocations of parental responsibility, an analysis that focuses only on purportedly gender-neutral allocations of parental rights would prove ineffective. The knowledge-at-birth requirement is, to be sure, not gender neutral at all: While all women know that they have borne a child, not all men are aware that they have fathered a child. ${ }^{179}$ Women would remain disproportionately burdened under such a test. ${ }^{180}$ Likewise, the primary-caretaker requirement is hardly gender neutral in a legal regime in which women are the presumed legal caretakers of their nonmarital children, a presumption that privileges fathers' freedom from legal parental responsibility for nonmarital children.

Careful scrutiny of the default rules of parental responsibility that animate parenting-related statutes would help courts avoid the primary pitfall of the approach used by legislatures and courts in the nineteenth and early twentieth centuries: the compromise of gender equality in the fulfillment of ostensibly rational policy interests. But altering the analysis of parenting-related statutes would not only change the result in Miller; it would also inspire a different conversation about parenting and gender. Recognizing how legal regimes bear on the allocation of parental responsibility would shift the focus away from a rights-based analysis that renders invisible women's legal and financial responsibility for nonmarital children and in so doing obfuscates the injury of that initial division of labor and duty. Unless the Court acknowledges that sex-based parentingrelated laws should receive the same rigorous analysis afforded all other sex-based laws, and extends that analysis to a priori allocations of legal parental responsibility, laws regulating parenting and reproduction will remain insulated from modern equal protection review.

178. Id. at 487 (Breyer, J., dissenting).

179. While Justice Stevens argues that men's lack of knowledge relieves them of parental responsibilities, a legal rule imposing a more demanding burden, such as holding men responsible for the possible outcome of sexual liaisons, is by no means foreign to American law.

180. One could argue that under the current categorical approach to equal protection analysis, a facially neutral law that disproportionately burdened women would not be subject to heightened scrutiny, as determined by the Court in Personnel Administrator v. Feeney, 442 U.S. 256, 272 (1979), which held that, in order to bring an equal protection challenge, the plaintiff must make a prima facie showing that the challenged law employs sex-based classifications and does not simply disparately impact women. While a formalist might argue that this represents the plaintiff's failure to demonstrate an equal protection violation, I would argue that it marks a failure of the equal protection doctrine to address and remedy state-sponsored sex discrimination. For a discussion of how facially gender-neutral statutes can mask and perpetuate gender-based discrimination and subordination, see Reva Siegel, Why Equal Protection No Longer Protects: The Evolving Forms of Status-Enforcing State Action, 49 STAN. L. REV. 1111, 1116-19 (1997). 